Portland State University

PDXScholar

1973

\title{
A Descriptive Follow-up Study of 21 Children from Parry Center
}

\author{
Paul Duke \\ Portland State University \\ William Handorf \\ Portland State University \\ Robert Lauer \\ Portland State University \\ Wayne Lee \\ Portland State University \\ Robert Rowe \\ Portland State University
}

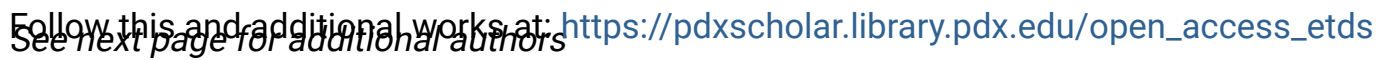

Part of the Child Psychology Commons, Counseling Psychology Commons, and the Social Work Commons

\section{Let us know how access to this document benefits you.}

\section{Recommended Citation}

Duke, Paul; Handorf, William; Lauer, Robert; Lee, Wayne; Rowe, Robert; and Stensberg, Robert, "A Descriptive Follow-up Study of 21 Children from Parry Center" (1973). Dissertations and Theses. Paper 1739.

https://doi.org/10.15760/etd.1738

This Thesis is brought to you for free and open access. It has been accepted for inclusion in Dissertations and Theses by an authorized administrator of PDXScholar. Please contact us if we can make this document more accessible: pdxscholar@pdx.edu. 


\section{Author}

Paul Duke, William Handorf, Robert Lauer, Wayne Lee, Robert Rowe, and Robert Stensberg 


\section{A DESCRIPTIVE FOLLOW-UP STUDY OF 21 CHILDREN \\ FRON PARRY CENTER}

by

Paul Duke

WiIliam Handorf

Robert Iauer
Wayne Lee

Robert Rowe

Robert Stensberg

A report submitted in partial fulfillment of

the requirements for the degree of

MASTER OF

SOCIAL WORK

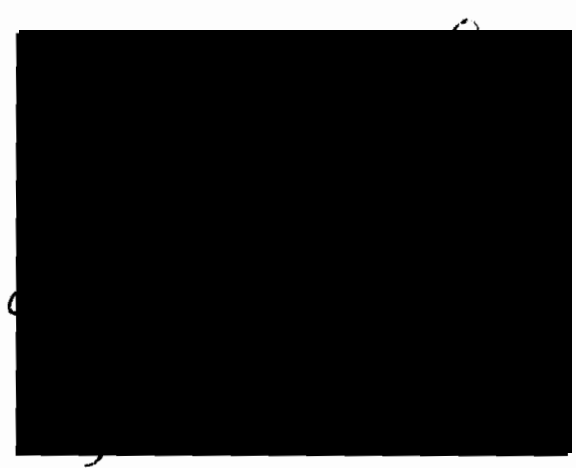

Portland State University

1973 
TABLE OF CONTENTS

Page

I. INTRODUCTION . . . . . . . .

II. METHODOLOGY . . . . . . . . . 11

III. FINDINGS . . . . . . . . . . 22

A. Descriptions

1. PreResidence . . . . ....

2. In-Residence ....... 25

3. Post-Residence . . . . 28

B. Data Analysis

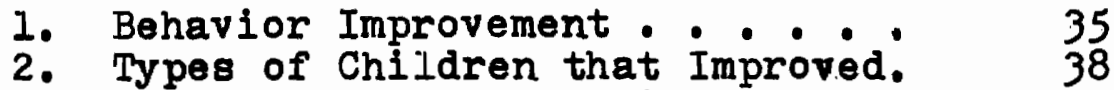

3. Parental Involvement in

Treatment ...... 47

4. Group Home Children ..... 51

IV. COMPARISON WITH PREVIOUS STUDY OF

18 BOYS .............. 56

v. CONCLUSIONS. . . . . . . 65

VI. $\triangle P P E N D I X$




I. INTRODUCTION

a. History

b. Review of Literature

c. Bibliography \& footnotes 


\section{INTRODUCTION}

The age-old question persists: Does an agencyoperated treatment program contribute significantly to a child's personal development and adjustment following release from the institution? Since it is the agency's responsibility to weigh the needs of the disturbed child and provide appropriate services according to those needs, their basic question--whether residential treatment or another mode of treatment is more effective-remains unanswered and, in many instances, uncontested. If residential child care benefits the disturbed child, which characteristics of that agency are conducive to the improvement of the child's behavior and re-adaptation? The following study will attempt to isolate such characteristics. We will provide behavior samples of twentyone emotionalily disturbed children before, during, and following treatment at The Parry Center. These behaviors are presented descriptively, and will relate to prior environmental influences (adjustment to home, school, etc.), treatment factors (those conducive to behavior change, those detrimental), and post-residential success. We will also compare these descriptions with The Parry Center's recent research study: Eighteen 
Boys - . A Descriptive Follow-Up Study (June 10, 1970.). Fund-raising and re-allocation of monies for the Parry Center and other child-care facilities are dependent upon the agency's presentation of positive treatment results, available through researched follow-up studies. Accordingly, the Parry Center has recognized a growing need for objective data and continued research pointing to successful re-adaptation of their population to the community. According to administrative staff at the Parry Center, past research and statistical studies from other treatment agencies are either outdated or irrelevant to the Parry Center's setting. Our study provides relevant, objective data through reference to and refinement of the aforementioned Eighteen Boys - . A Descriptive Follow-Up Study. Specifically these criteria are:

(1) a systematic description of the current Iife situation of twenty-one children who were in a specialized treatment program at Parry Center,

(2) provisions for some guidelines for ongoing follow-up studies for all children who have been served by Parry Center,

(3) contributions toward a method of assessing the agency's practices. 1

A. History

The Parry Center (formerly The Home, and The Children's Home) is the oldest care facility for children in 
Portland, Oregon It began in 1867 through the efforts of a small group of women to care for the needs of orphaned or neglected children in immigrant wagon trains which had traveled across the plains. After four years of this work--financed largely by entertainments, concerts, and bazaars--two lots and a small house were purchased, establishing the facility then known as The Home. The objective changed from an orphanage to providing care for children from broken homes in as uninstitutional an atmosphere as possible. It was then supported by concerned citizens and wealthy benefactors. The first permanent facility was constructed in 1884. The present facilities, relocated, are on a thirteen acre plot bought by a generous benefactor, Mrs. P. J. Mann. Facilities include cottages, administration building, auditorium, and gymnasium. The cottages provide quarters for twenty-five children, a house mother and a cook are in charge of each complex.

The Children's Home remained primarily a custodial agency until the mid $1950^{\prime} \mathrm{s}$. Child Welfare studies, growing needs, and staff concerns prompted the institution to look into adding to their agency professional personnel. The year 1952 was the landmark for transition, as the institution hired its first social worker who assumed directorship of the agency. During this 
phase the institution began its metamorphosis from a custodial to a treatment organization which in turn altered agency philosophy, intake criteria, and staff hiring practices.

In 1965 a significant transition took place, durIng the residence of this study's population, in that the policy of intake changed to providing services for neurotic children and chlldren with behavior disturbances. The program required that the children have average intelifence and enough self-control to live in an open setting. ${ }^{2}$ At this time Parry Center provided residential care of children between the ages of six through seventeen. A variety of complications arose from the Parry Center staff with some of the children in the age range of 13 through 17. Many exhiblted dangerous actingout episodes, stealing, running from the institution, physical assertiveness toward the other children, and destruction of Parry Center property. Many of these same children exhibited no remorse concerning these actions, making it extremely difficult for the staff to make the child aware of the unwanted behavior. Thus, these behaviors continued with little positive change. The above behavioral factors in particular should be considered in terms of the effect treatment had on the children (and also upon the successful readjustment following treatment) at the Parry Center. 
Recently, the Parry Center has perceived their lack of facilities for children with acting-out, behaviors. They have also altered intake criteria and have restricted population to pre-adolescent children. The following study's population differs from the Parry Center's present population in the abovementioned ways. B. Review of Literature

In our exploration of literature we have observed several general reasons given by other studies for underthing a post-residential study. The following statements relate clearly to our study's rationale for a follow-up research of emotionaliy disturbed children. According to Viola and Sanford Weiss, authors of A Follow-Up Study of Children Released From Residential Treatment Centers (Jewish Children's Home Service of New Orleans, Louisiana), there are three general reasons (1) to explore, evaluate and seek a means of validation of residential child-care services; (2) to develop a clear conceptual practice which requires validation and isolates those that lend themselves to research; and (3) above all, to develop procedures for testing the results and sorting successes from failures. 3

A study by Delores Taylor and Stuart Alpert entitied Continuity and Support Following Residential Treatment states I 
"The primary purpose of a post-discharge study . - is to examine levels of adaptation achieved by children who had undergone residential treatment, and the environment, agency, and other professional supports necessary to increase the opportunities of the youngsters' well being . . and to study thpse elements enhancing capacities and behaviors." 4

Whether to validate residential child care, to examine levles of adaptation following discharge, or to develop procedures for sorting successes from failures, whether for funding, obligation, or desire, we, with the Parry Center and other child-care agencies. are discovering an increasing urgency for informative. objective follow-up study.

The Bellfaire Follow-Up Study in Cleveland, Ohio, beginning in 1947. though inactive for many years, has impressed us with its methods of research and postdischarge observation of children. For example, the Bellfaire Study findings show that there is significance in combining many views of success into a compoiste picture: ". - and this does not preclude the importance of individual evaluation, such as a child's report about his own feelings of being helped, or in the parents' judgment of the child's improvement." 5 Our study tends to align itself with that of the Bellfaire research, giving greater attention to the child's self-report. Additionally. Bellfaire Study explores the success of the child following his residential treatment 
in terms of his re-adaptation to society, parents, and school. For example, is the child able to perform adequately in school? Is his attention span short? Does his temper flare under academic stress? How well does he get along with his peers? From these adaptive behavioral descriptions, the Bellfaire Follow-Up Study was able to determine the results of treatment after release from the agency. Our study tends to confirm the child's success, also, in terms of adaptive behavioral descriptions. There has been little research on the process and descriptive outcome of treating emotionally disturbed children. "Researchers as well as clinicians have repeatedily claimed that it is difficult to measure an elusive concept such as 'success'." 6 our review of literature may appear brief; however, this is due to the fact that there is a lack of substantive research. "Few residential programs evaluate the outcome of their work in rigorously designed, well-controlled, scientifically objective studies." (For further information pertaining to descriptive, short-term, and follow-up studies, see Chapter Note \#8). We, in our study, attempt to move a step further towards providing a more objectively scientific, better controlled study of emotionally disturbed children following residence at the Parry Center. 
C. Bibliography and Footnotes

Chapter Notes

1. Eighteen Boys: A Descriptive Follow-up Study Portland Children's Treatment Study Center, a demonstration project, October 1, 1959, through June 30, 1963; Doris Rodman, Dorothy Bateman, Charlotte Berg, Margueritte Jette, Sonja Matison, Rosalie Smitz. p. 3 .

2. Intake Policy, Parry Center for Children, Portland, Oregon, 1964, by Parry Center Staff, p. 2.

3. "Follow-Up Study of Children Released from Residential Treatment Centers." Weiss, Viola and Weiss, Sanford. Mimeographed New Orleans, La.," Jewish Children's Home Service, 1969.

4. "Continuity and Support Following Residential Treatment." Child and Family Services of Connecticut. Delores A. Taylor, Ph.D., Stuart W. Alpert. Child Welfare League of America, Inc. New York, N.Y., 1973, p. 1 .

5. Allerhand, Melvin E., Weber, Ruth E., and Haug, Marie. Adaptation and Adaptability: The Bellfaire Followup Study. New York! Child Welfare League of America, 1966.

6. "The Concept of Success in Residential Treatment, An Administrator's View." Child Welfare 43 (October, 1964), p. 423-26.

7. Joint Commission on Mental Health of Children. "Crisis in Mental Health. Challenge for the 1970's" New York! Harper \& Row, 1969, 1970, p. 273.

8. These are all available published follow-up studies to date 1

a. Allerhand, Melvin E., Weber, Ruth E., and Haug, Marie. Adaptation and Adaptability: The Bellfaire Follow-up Study. New York, Child Welfare League of America, 1966.

b. Bulberic, Richard. Residential Work with Children. London: Pergamon Press, 1966. p. 97131; 134-180. 
c. Davids, Anthony, Ryan, Richard, and Salvatore, Peter. "Effectiveness of Residential Treatment." Journal of Orthopsychiatry 38 (April, 1968), p. 469-75.

d. Mora, George, et al. "A Residential Treatment Center Moves Towards the Community Health Model." Child Welfare 48 (December 1969), p. 585-90.

e. Naylor, H. Kelly, and Young, Vera. "Follow-up Study of Maladjusted Children Identified for Residential Treatment in Hawaii." Mimeographed. Honolulu, Hawaii: Hawaii Department of Health Mental Health Division, n.d.

f. Taylor, Delores, and Alpert, Stuart, Continuity and Support Following Residential Treatment. New York: Child Welfare League of America, forthcoming.

g. Weiss, Viola, and Weiss, Sanford. "Follow-up Study of Children Released from Residential Treatment Centers." Mimeographed. New Orleans, Ia. Jewish Children's Home Service, 1969.

h. Polansky, Norman, et al. "Retreived from Limbo." 
II. METHODOLOGY

a. Purpose

b. Scope and Population

c. Hypothesis: Collection of Data

d. Method of Ranking Children

e. Statistical Treatment 
II. METHODOLOGY

\section{A. Purpose}

This follow-up study represents an attempt to describe, systematically, the patterns of behavior and current life situations of children placed in Parry Center between July, 1963 and December, 1965, and serves as a sequel to the initial study completed in June, 1970. by Parry Center. As in the initial study, pre-, in-, and post-residence data were collected to facilitate an examination and an understanding of each child's progression in terms of his life situation and rate of behavior change. The secondary aims for this study included a continuation of an on-going evaluation of Parry Center and to establish communication with its former residents.

\section{B. Scope and Population}

The first follow-up study completed June, 1970, had a population of eighteen boys which represented all the children who had been admitted to Parry Center's Treatment Study Center between October, 1959 and June, 1962. Due to a change in intake criteria from the initial study, and to facilitate the comparison between the two studies, the staff at Parry Center determined that the 
population for this follow-up study should include all those children admitted between July, 1963 and December, 1965. This population is composed of twenty-one children, nineteen boys and two girls, showing an age range of twelve through eighteen years at the time of this study. The age range at admission extended from five years, eleven months through eleven years, four months, with a mean of eight years and six months.

Pre-residence, in-residence, and post-residence data were obtained on twolve of the total " $n$ " of twentyone children.

Post-residence data was not available for nine children due to:

$$
\begin{aligned}
& \text { 1. An inability to locate four children. } \\
& \text { 2. Refusal to cooperate by two children. } \\
& \text { 3. Parents did not want child interviewed } \\
& \text { in one case. } \\
& \text { 4. One child was located, but did not respond } \\
& \text { to letter. }
\end{aligned}
$$

In other words, complete data was obtained on twelve of the twenty-one children, and data on the remaining nine children was limited to pre-residence and in-residence.

C. Hypotheses, Collection of Data

1. The first hypothesis of this study is that the child's behavior improves from pre-residence to in-residence. Prior to being placed in a residential program, 
the child because of his emotional and/or behavioral problems may be the subject of a chaotic and rejecting onfironment. A therapeutic community model such as Parry Center attempts to implement a total treatment program which consists of the blending of a day-to-day living experience with the formal treatment modalities. Inherent in this type of program are environmental structure, consistency in response to his behavior so that he may be able to make predictions of consequences, expectations and limit-setting controls for creating a sense of security, a school and recreational program geared to his needs and abilities, and an opportunity to identify with warm and supportive adult models. Before placement it is assumed that the child does not have access to many of these environmental necessities. Consequently, the child, while attempting to grow and mature must often contend with inadequate parents and with an inadequate ego--in terms of his lacking a functioning self-regulation mechanism.

Regardless of whether the behavior change is due to the therapeutic community, a result of nautral growth and maturation, a moratorium from a pathological family enfironment, or a combination of these and others--the end result we hypothesize is a reduction in negative, self-defeating behavior.

2. It is also hypothesized that parental involvement in the child's treatment results in a positive 
behavioral change. If the family is viewed as a system, it follows that any imbalance within that system will probably have some effect in the functioning of the other members. When this imbalance causes disruption or other pathological symptoms between the parents, there is strong clinical evidence that the children will also manifest emotional and/or behavioral symptoms. As the child, in a sense, learns his inappropriate behavior within the family system, it would seem to follow that if the parents were actively involved in their child's treatment and relatively motivated to work on their own problems, the child's overall behavior should improve. The answers to the following two questions which could not be hypothesized were sought through inspection of the data,

1. Behavioral change is greater in what kinds of children?

2. In what ways do children who are placed in group homes differ from children who are not placed at a group home?

As in the initial study, interview by questionnaire was considered the most appropriate mode for collection of post-residence data. Four questionnaires were utilized in obtaining necessary data,

1. Pre-residence--data from Parry Center records (Appendix A)

2. In-residence--data from Parry Center records (Appendix B) 
3. Post-residence follow-up--data obtained by interview with parent* (Appendix C)

4. Post-residence follow-up--data obtained by interview with child (Appendix D)

The Behavior Rating Scale (BRS) which was an integral part of the pre-, in-, and post-questionnaires was designed to rate on a scale of zero to three the child's degree of behavioral problem. A zero rating means "no problem" with respect to a particular behavior; a 1 rating means "mild problem," a 2 rating means "serious problem;" and a 3 rating means "very severe problem." For the pre- and in-residence questionnaires, the record reviewers determined the score by a careful and thorough examination of each child's record. Although the rating was subjective in nature, the raters' method was to identify specific behavioral incidents and to rate their degree of severity according to frequency and quality of the particular behavior.

Regarding the Behavior Rating Scale with respect to the parents'. post-residence questionnaire, the interviewers determined the rating subjectively after a brief discussion with the parent on each behavior category. The emphasis was to ask open-ended questions to allow

* Due to the absence of many natural or step parents, other significant adults having sufficient awareness of child's current functioning were chosen to be interviewed as "parent" (i.e. group worker, parole officer, group home parent). 
the parent to describe his onild's funotioning, rather than specifio and often threatening questions whioh could result in a minimizing of the problem. The six graduate Soclal Work studenta: conduoting the study were divided equally into a reoord reviewing team and an interviowing team. The rooord revlewers had the responsiblilty of completing questionnalres \#1 and \#2 from information obtained in eaoh onlld's rooord at Parry Center. The interviowers had the responolbility of ensuring the completion of follow-up questionnalres \#3 and \#4 via interview with the ohild and parent. The research team determined that in two oasos ("1210 and \#220), 1t would be acceptable to allow the surrogate parent to flll out the follow-up questionnalre (parent) at their convenlence without boing interviewed by one of the interviow team due to logistical difficultios. The follow-up questionnalre (ohild) was adminloterod, with one exception, by members of the interviow toam. The exception involved a child who refused to be interviowed by a member of the interview toam, subsequentiy he agreed to being interviowed by a staft mombor of Parry Center.

The record reviowers met frequentily to disouss record reviewing mothods and read soveral sample rooords in proparation for their task. The interviowers oonducted pre-test interviews and role-played to onsure a rollablo 
unifomity and consistency in interviewing approach.

These instruments (questionnaires) were designed to obtain:

1. A behavior description of each child before, during, and after residence. The data needed to describe the child's behavior was extracted primarily from theBehavior Rating Scale which is included in the pre-residence, in-residence, and follow-up (parent) questionnaires.

2. A description of the child's family situation, school functioning, relationship with others, and general life situation. For purposes of describing each child's previous and current life experiences, the following general categories were selected for data grouping.

$$
\begin{aligned}
& \text { a. Living situation } \\
& \text { b. Socialization } \\
& \text { c. Self-awareness } \\
& \text { d. Authority } \\
& \text { e. Relationshipg }
\end{aligned}
$$

(1) Peer

(2) Adult

(3) Parent

f. Sohool

g. Parry Center impressions

h. Follow-up services

D. Method for Ranking Children According to Behavioral Change (based on data from the Behavior Rating Scale)

Since describing the child's behavior patterns was considered a primary task for this study, it was decided that it would be worthwhile to rank each child with respect to the percentage of behavior change (Positive or negative) between two different time periods,

1. The percentage of behavioral change from pre-residence (time one)* to in-residence (time two )*.

\footnotetext{
* It should be noted that subsequent reference to pre-, in-, and post-residence will generally be referred to as time one, time two, and time three, respectively.
} 
2. The percentage of behavioral ohange from in-residence (time two) to post-residenoe (time three)*.

The percentage of behavior change from preresidence (time one) to in-residenoe (time two) was determined by totaling the soores for each ohild for each time period. The differenoe between these two periods was converted into a peroentage of behavioral change and the children were ranked from the highest percentage of positive behavioral ohange down to those children with the lowest or negative peroentage of behavioral change.

The same method was used for determining the bohavloral change from in-residence (timo two) to postresidence (time three) except that only twolve of the total population of twonty-one wero ranked.

\section{E. Statistical Treatment}

Since the purpose of this study was to obtain, organize and present data to Parry Conter rogarding former residents, the statistical mothod chosen wad primar1ly desoriptive in nature (1.0, tablos, flgures) rather than inferential. However, a t tost was ut1lized in our first hypothesis regarding behavioral improvemont botwoen

* It should be noted that subsequent reforonoe to pre-, in-, and post-residence w111 gonorally be reforred to as time one, time two, and time three, respoctively. 
the three time periods.

Much data collected could not be treated in the

time available and is stored for use of Parry Center Staff and investigators. 
III FINDINGS

A. Descriptions

1. Pre-Residence

(Figures 1-5)

2. In-Residence

(Figures 7-8)

3. Post-Residence

(Figures 9-13) 


\section{FINDINGS}

A. Descriptions

1. Pre-residence Description:

The study population was drawn from several major sources. Fifty-three percent of the children came from homes other than their own. Ten of the children came in to residence from their own homes, 8 came from foster homes, 2 from the Multnomah Juvenile Detention facility and 1 from Eastfield Childrens Home. Eleven of the residents were in the custody of their natural parents at the time of placement, 1 was in the custody of stepparents and 9 were wards of the court.

Fig. 3-1 Number of Prior Placements Placements Children

$\begin{array}{lc}\text { Eight } & 1 \\ \text { Five } & 3 \\ \text { Four } & 1 \\ \text { Three } & 1 \\ \text { Two } & 1 \\ \text { One } & 7 \\ \text { None } & 7 \\ \text { Total } & 21\end{array}$

Sixty-seven percent of the children had one or more placements prior to their residency at Parry Center. The disruptions characterizing the lives of these children is demonstrated by the high incidence of separation 
from their parental homes. It is difficult to separate the cause and effect relationship of these multiple placements and behavioral problems exhibited by these children.

Fig. 2-2 Marital Relationship of Natural Parents at Time One

Marriage Intact

Separated

Divorced

Marriage Terminated By Death Unknown Total

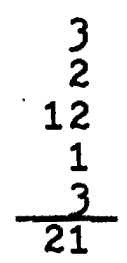

Intellectual, School and Psychological Data

Intellectual functioning in children, particularly children with severe emotional problems, is difficult to measure. I.Q. scores were available for 17 of the 21 children in the study. These scores were obtained from a variety of different tests administered under differing conditions, so the scores are presented as only a rough estimate of intelligence.

\section{Fig. $3-3$ I.Q. Ratings}

I.Q. Scores

Children

Below Average ( 90 or less)

Average (91 to 110)

Above Average ( 110 and Above)

Unknown

Total

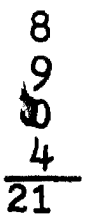

School problems, both behavioral and learning, were common presenting problems among these twenty one 
children. Information in the case records was not adequate to give a break-down of age-appropriate grade functioning at time of placement. The learning demands, social expectations, the value placed on order and cooperation and the structured environment of the educational system make the emotionally disturbed child highly visible to adults in this setting.

The study population included a large number of children with histories of abuse or negleot suffered during the early developmental years. Case records revealed that 13 of the 21 children had experienced some form of abuse, neglect or both at some point in their history.

Fig. 3-4 Alleged Abuse and Neglect Abuse or Neglect Children
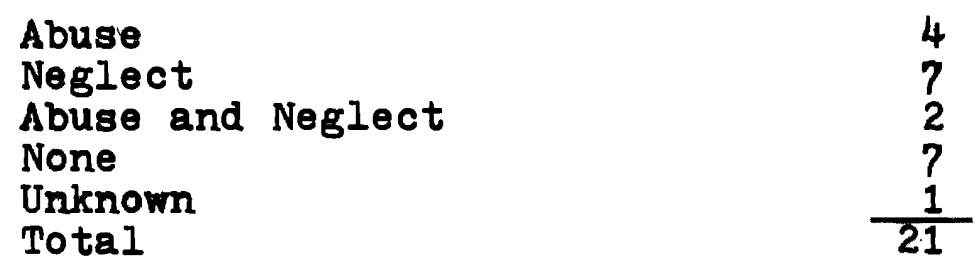

Seventy percent of the 20 children were found to have experienced some form of abuse or neglect.

The BRS was used to obtain a group score for each problem area at the time of placement. The group score allows for a ranking of problem areas in terms of their frequency and intensity. It was felt that this system 
provided a more objective and descriptive measurement of presenting problems than did formal peychiatric diagnosis.

Fig. 3-5 Ranking of Problem Areas at Time One

Problem Area

1) Relationship With Parents

2) Relationship With Peers

3) Verbal Aggression

4) Relationship With Adults

5) Authority Problems

6) Physical Aggression

7) Motor Problems

8) Withdraw From Physical Contact

9) Sleeping Problems

10) Verbal Withdrawl

11) Eating Problems

12) Language Problems

\section{Group Score} From BRS

In addition to the above twelve problem areas, ? of the children exhibited some distortion of reality, 4 exhibited some form of ritualistic behavior and 6 exhibited both ritualistic behavior and distortion of reality.

2. In-Residence

At the time the children were discharged from Parry Center residence, time two, the average age for all 21 in the population was 12 years, 2 months with a range from 8 years, 10 months to 15 years, 10 months. After release from residence the children were placed as follows : 
Fig. 2-6 Living Situation Following Residence

Returned to one or both parents Parry Center foster home/group home

Placed directly in institutions

(J.D.H., MeClaren School for Boys,

Dammasch State Hospital)

Discharges from Parry Center were planned in all but one situation. Fourteen children were discharged by staff plan having received maximum benefit from Parry Center. Six were staff planned discharges because the child was not able to respond or use Parry Center and needed other help. One child was discharged to a parent against agency planning.

The prior study revealed a positive relationship between the child's treatment progress and his parents' involvement with Parry Center staff in the treatment. At time two in this study parents were recorded as involved in treatment as follows:

Fig. 2-7 Parents' Involvement In Treatment

A. Parents involved in treatment with goals of personal change and in support of child's treatment

B. Parents in contact with staff in support of child's treatment

C. Parents had no contact with staff regarding treatment

D. Parent in contact with staff but didn't support treatment 
E. Parent had no contact with staff regarding chid's treatment but sought help with another agency

At the time of release the parent-child relationship was judged to have shown great improvement since the time of placement at Parry Center for three children. For 13 the parent-child relationship continued to be significantly problematic. Information was not available for judging in five cases and in most of these, the reason stemmed from lack of parental contact. Followup services were given by staff on behalf of 11 of the 21 children.

Parry Center Records indicate that for 17 children medications were used in treatment to control behavior during residence.

The problem behaviors at time two as measured from the study's Behavior Rating Scale centered on the broad area of relationships with others. The ranking of problems by group score in terms of their frequency and intnesity is as follows: 
Fig. 2-8 Rankings of Problem Area At Time of Release

\section{Problem Area}

1) Relationship with Parents

2) Relationship with Peers

3) Relationship with Adults

4) Authority Problems

5) Withdrawal from Physical Contact

6) Physical Aggression

7) Verbal Aggression

8) Motor Problems

9) Sleeping Problems

10) Verbal Withdrawal

11) Toileting Problems

12) Language Problems

13) Eating Problems
Group Score

From B.R.S.

29

29

28

23

21

20

19

5
3

In addition to the above, six children were recorded as exhibiting ritualistic behavior. Seven of the 21 exhibited some distortions of reality at this time period. Two showed both (\#208, \& \#219), while ten children showed neither. Four showed total behavior scores that were worse at time two than their total behavior scores for time one. All others showed various degrees of improvement in their behavior scores.

3. Post-Residence:

Of the 21 children in the study's population described at time one and time two, only 12 appear in the study at time three. The nine absentees at time three are accounted for as follows : 
Fig. 2-9 Cases Missing at Time Three

Unable to locate

Parent refused interview

Child refused interview Located out of State with Total no response to inquiry

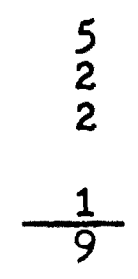

The time three children present a complex picture and a reversal of behavioral improvement measured against their time two ratings and expectations. Several hypotheses are suggested for this reversal of trends and will be considered further on in the study. At the time of the study, the 12 show an average age of 15 years 8 months, ranging from 13 years 0 months to 18 years 1 month. Eleven subjects are male, one is female.

At the time of the conclusion of the study, i.e., at the time of subject contact, half of the subjects were still tied indirectly to Parry Center by reason of their living situation, namely, a Parry Center group foster home. Descriptively, the 12 were classified as follows:

Fig. 3-10 Living Situation--Time of Interview

Own home

Parry Center foster group home

1
6
1
3
$1 *$

Institution

Other

* Subject was living alone, but under outside supervision of parole officer. 
Enroute to their living situation at the time of contact with the study's interviewers, the subjects were traced from time of discharge from Parry Center treatment to their living situation at time of contact. At the time of discharge, six were routed directly to a Parry Center foster group home. Of these six, five remained there with no intermediate moves up until contact with the time three interviewer. One of the subjects who had been institutionalized upon discharge from Parry Center had experienced five different living situations since the original placement. At time three, the subject was living alone without constant supervision. A charted description, encapsulating individual case checks, appears as follows:

Fig. 2-11 Living Situations Since Discharge

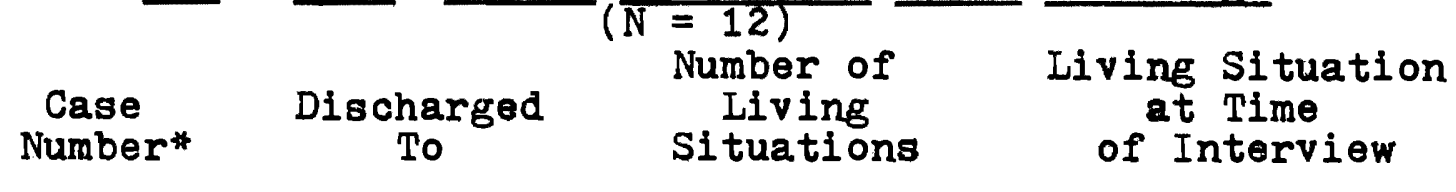

$\begin{array}{llll}220 & \text { D } & 5 & \text { E } \\ 207 & \text { A } & 3 & \text { D } \\ 210 & \text { D } & 4 & \text { D } \\ 218 & \text { B } & 3 & \text { B } \\ 217 & \text { D } & 4 & \text { D } \\ 208 & \text { D } & 4 & \text { A } \\ 202 & \text { A } & 1 & \text { B } \\ 209 & \text { B } & 1 & \text { B } \\ 204 & \text { B } & 1 & \text { B } \\ 214 & \text { B } & 1 & \text { B } \\ 215 & \text { B } & 1 & \text { B } \\ 211 & \text { B } & 1 & \end{array}$

* Cases ranked according to time three B.R.S. 
In above figure:

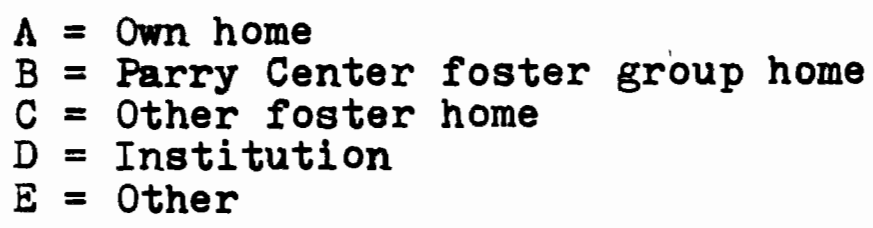

The numbers and types of ancillary services utilized by the 12 from the time of discharge until time of contact with the interviewer is as follows:

Fig. 2-12 Follow-up Services Since Discharge

$$
\begin{array}{lc}
\text { (N - 12) } & \\
\text { Time Two - } & \text { Time Three } \\
\text { (Time of } \\
\text { Time Three } & \text { Interview) }
\end{array}
$$

Physician

Psychiatrist

Psychologist

Social Worker

Religious Counselor

Other

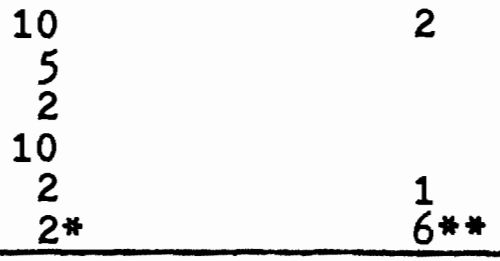

* School Counselor; Parole Officer

* School Counselor, MacLaren Counselor, JDH Counselor, Welfare Social Worker; Parole Officer

Of the twelve retrospective impressions of Parry Center, half of the group left with positive attitudes toward Parry Center, perceiving their treatment as having been beneficial. This information was abstracted from time three questions dealing with dislikes and final impressions. The other half of the group recalled negative aspects of the treatment program. These included memories of rough physical treatment by house parents, 
inequity of aggressive disciplinary measures discriminatively applied, the harrassment of younger children by older children, the impression of being 'put down' or being treated as 'crazy' by the staff, and a lack of experiences within the institution which would prepare the child for life outside of the institutional setting. Time three contact found eleven of the twelve enrolled in sohool. Only one had dropped out, leaving school after the tenth grade. Of the eleven enrolied in school, five were enrolled in a formal elementary or secondary educational program. Of the remaining six, two were enrolled in special education programs (underachievers who did not expect to complete formal education), while four were in vocational training programs. One of these had completed high school and was attending a technical vocational program at a local community college.

Sumilar to time one and time two, the BRS was used to obtain a group score for each problem area, ranking the problem areas in terms of their frequency and intensity, using the same scale. 
Fig. 3-13 Problem Area at Time of Interview

$$
(N=12)
$$

Problem Area

1) Relationship with Adults

2) Relationship with Parents

3) Authority Problems

4) Withdrawal from Physical Contact

5) Relationship with Peors

6) Verbal Aggression

7) Eating Problems

8) Motor Problems

9) Physical Aggression

10) Verbal Wi thdrawal

11) Language Problems

12) Sleeping Problems

13) Toileting Problems
Group Score

From BRS

11

10

9

9

8

7

7

5

5

4

3

In addition to the above thirteen problem areas, four of the children exhibited some distortion of reality, two exhibited some form of ritualistic behavior. One exhibited both ritualistic behavior and some distortion of reality, while six exhibited neither of these distrubances. 


\section{FINDINGS}

B. Data Analysis

1. Behavior Improvement (Tables 1-3)

2. Types of Children That Improved (Tables 4-5)

(Figures 1-3)

3. Parental Involvement in Treatment (Table 6) (Figure 4)

4. Group Hone Children 


\section{B. Data Analysis}

\section{Behavior Improvement}

One of the study's main hypotheses suggests that a child's behavior should improve over time from the pre-residence to the end of residence to the post residence times of measurement. We can measure behavior improvement by examining the raw scores from the Behavior Rating Scale,

\section{Table 1 Behavior Rating Scale Raw Scores}

$\begin{array}{cccc}\begin{array}{c}\text { Subject } \\ \text { Code }\end{array} & \begin{array}{c}\text { Time } \\ (\mathrm{N}=21)\end{array} & \begin{array}{c}\text { Time } 2 \\ (\mathrm{~N}=21)\end{array} & \begin{array}{c}\text { Time } \\ (\mathrm{N}=12)\end{array} \\ 201 & 13 & 4 & \\ 202 & 19 & 12 & 7 \\ 203 & 19 & 2 & 7 \\ 204 & 24 & 7 & \\ 205 & 22 & 1 & \\ 206 & 11 & 3 & 4 \\ 207 & 9 & 14 & 6 \\ 208 & 13 & 11 & 6 \\ 209 & 17 & 7 & 7 \\ 210 & 18 & 15 & 10 \\ 211 & 18 & 5 & \\ 212 & 15 & 14 & 9 \\ 213 & 11 & 13 & 8 \\ 214 & 19 & 8 & 8 \\ 215 & 14 & 10 & 14 \\ 216 & 18 & 23 & \\ 217 & 19 & 15 & \\ 218 & 15 & 4 & 2 \\ 219 & 24 & 18 & \\ 220 & 19 & 23 & 5 \\ 221 & 18 & 5 & \end{array}$

We observe that 17 of the 21 children did improve their behavior rating scores from time 1 to time 2 . Four Children actually got worse, however. We also observe that between time 2 and time 3, eight of the 12 
children contacted showed improvement, three got worse, and one child scored the same.

For eleven of the twelve children interviewed the raw scores show improvement in behavior from the time 1 measurement to the time 3 measurement, a period of seven to eight years. The twelfth child improved at first by four points but then got worse by four points, ultimately remaining the same. None of the children interviewed, then, got worse overall. This leaves a net effect of improvement for the children interviewed.

The above rating doesn't account for specific behavioral improvements in identified problem areas, but the overall trend showed substantial improvement for almost every subject. In some problem areas a child may have improved while getting worse in others or developing new problems. This effect has been termed displacement or symptom substitution.

To analyze behavior improvement in another way we have computed the mean behavior score for each time period. Since a larger score indicates more severe problems, the decrease in the size of the means clearly implies improvement. The means and standard deviations of these distributions have been computed as follows 


\section{Table 2}

$\begin{array}{lccc} & \begin{array}{c}\text { Time } 1 \\ (\mathrm{~N}=21)\end{array} & \begin{array}{c}\text { Time } 2 \\ (\mathrm{~N}=21)\end{array} & \begin{array}{c}\text { Time } 3 \\ (\mathrm{~N}=12)\end{array} \\ \text { Mean Behavior Score } & 16.90 & 10.19 & 7.08 \\ \text { Standard Deviation } & 4.07 & 6.46 & 3.06\end{array}$

From these figures a $t$ test was used to test the one tailed significance of the difference between two means, for time 1 and time 2 improvement, for time 2 and time 3 improvement, and for time 1 and time 3 improvement. These were computed with the following results !

\section{Table 3 Tests of Significance}

$$
\begin{aligned}
& t_{1,2}=1.928-\text { significant to } .05 \text { level } \\
& t_{2,3}=1.873-\text { significant to } .05 \text { level } \\
& t_{1.3}=7.856-\text { significant to } .01 \text { level }
\end{aligned}
$$

Behavior improvement is significant between time 1 and time 2 and between time 2 and time 3, but behavior improvement is most significant over the longer period, time 1 to time 3. These findings lend support to the hypothesis: Behavior seems to improve over time from pre-residence to in-residence to post-residence as measured by these instruments.

The next question that could be asked is, "Why?". There could, of course, be a multitude of explanations. One inference might be that Parry Center treatment shared 
some of the credit, especially in view of the continued responsibility of the center for several of the subjects. However this assertion requires further examination due to the observation that those who went to Parry Center's Group Home did worse from time 2 to time 3 than the rest in Group Home children of the sample. This will be discussed in a later section. Another inference might view improvement as a function of expected growth in childhood. These sub-hypotheses might be subject for future investigation.

2. Types of Children that Improved

One of the major tasks of this study was to identify the variables that appear to account for the degree of success or failure experienced by the children during residence at Parry Center. This brings us to our second major research question. Behavioral change is greater in what types of children? The population was ranked in terms of improvement from time 1 to time 1 from their scores on the BRS. The difference between the total score for each child at time 1 and time 2 provided a raw score of behavioral change. The percent of change from time 1 to time 2 was computed for each child and this percentage was used to rank the subjects. A percentage score was used to allow for the differences in time 1 scores which serve as an upper limit on the amount of 
numerical change possible for each child.

Table 4 Time 1-Time 2 Improvement Ranking From BRS

\begin{tabular}{|c|c|c|c|c|}
\hline Code & $\begin{array}{l}\mathrm{T}-1 \text { BRS } \\
\text { Score } \\
\end{array}$ & $\begin{array}{c}\text { T-2 BRS } \\
\text { Score } \\
\end{array}$ & $\begin{array}{c}\text { Dif. } \mathrm{T}-1 \text {, } \\
\mathrm{T}-2\end{array}$ & $\begin{array}{c}\% \text { of } \\
\text { Change }\end{array}$ \\
\hline $\begin{array}{l}205 \\
203 \\
218 \\
206 \\
211 \\
221 \\
204 \\
201 \\
209 \\
202 \\
202 \\
215 \\
219 \\
217 \\
210 \\
208 \\
212 \\
213 \\
220 \\
216 \\
207\end{array}$ & $\begin{array}{r}22 \\
19 \\
15 \\
11 \\
18 \\
18 \\
24 \\
13 \\
17 \\
19 \\
19 \\
14 \\
24 \\
19 \\
18 \\
13 \\
15 \\
11 \\
19 \\
18 \\
9\end{array}$ & $\begin{array}{r}1 \\
2 \\
4 \\
3 \\
5 \\
5 \\
7 \\
4 \\
7 \\
8 \\
12 \\
10 \\
18 \\
15 \\
15 \\
11 \\
14 \\
13 \\
23 \\
12 \\
14\end{array}$ & $\begin{array}{r}21 \\
17 \\
11 \\
8 \\
13 \\
13 \\
17 \\
9 \\
10 \\
11 \\
7 \\
4 \\
6 \\
4 \\
3 \\
2 \\
1 \\
-2 \\
-4 \\
-5 \\
-5\end{array}$ & $\begin{array}{r}95 \\
89 \\
73 \\
72 \\
72 \\
72 \\
70 \\
69 \\
58 \\
57 \\
36 \\
28 \\
25 \\
21 \\
16 \\
15 \\
06 \\
-18 \\
-21 \\
-27 \\
-55\end{array}$ \\
\hline
\end{tabular}

The following material represents our attempt to isolate the factors which appear to be highly associated with improvement and, in part, to describe what type of children experience the largest amount of behavioral change between Time 1 and Time 2 .

The serious psychological ramifications of physical abuse and neglect suffered during the early development years has been well established by many studies and clinical cases. We had suspected that children from our 
study population who had histories indicating experiences of abuse and neglect would experience fewer successes during treatment than would children who had not been subjected to these abuses.

Comparison of the children who showed the most improvement during residential treatment with those who showed minimal improvement or deterioration during treatment indicates that the association between improvement and a history of abuse or neglect is stronger for neglect than it is for abuse. Two of the children from the top $1 / 3$ of the Time-2 Improvement Ranking had histories of abuse and two from the bottom $1 / 3$ of the population had similar histories. However, only 1 child out of the 7 in the top $1 / 3$ of the ranking had a history of neglect but 5 out of 7 of the bottom $1 / 3$ had experienced parental neglect during early childhoold.

\section{Fig. 3-1a Association of Neglect and Improvement}

$$
\begin{gathered}
\text { Top } 1 / 3 \text { of } \mathrm{T}-2 \\
\text { Improvement Ranking } \\
\begin{array}{c}
\text { Bottom } 1 / 3 \text { of } \mathrm{T}-2 \\
\text { Improvement Ranking }
\end{array}
\end{gathered}
$$

No Neglect

Neglect

* 1 suffered both neglect and abuse

With this particular population, histories of early neglect appear to be positively associated with little improvement or deterioration during residential 
treatment.

Residential treatment, for many emotionally disturbed children, constitutes only one of many treatment experiences that they may encounter throughout their childhood and adolescence. Of these 21 children, only 9 were returned to their parental homes after discharge from Parry Center. Five of the 7 children in the bottom $1 / 3$ of the Time-2 Improvement Ranking were discharged to other institutions. Five of these same 7 children were discharged because they were unable to respond to Parry Center's treatment program. Only one of the other 14 children was discharged to another institution. Eight were discharged to their own homes and 6 went to Parry Center group homes for continued treatment in a less controlled evironment.

An analysis of individual problem areas from the BRS revealed that six of these problem areas seemed to be significant separating the top $1 / 3$ of the Time-2 Improvement Ranking from the bottom $1 / 3$. In all six of these problem areas most of the children in the top $1 / 3$ of the Time-2 Improvement Ranking improved while the children in the bottom $1 / 3$ either remained unchanged or deteriorated in these same six areas. There was no such olear trend established for the other six scaled areas of the BRS, verbal aggression, motor problems, sleeping problems, verbal withdrawl, eating problems 
and language problems.

\section{Relationship with Peers}

$$
\begin{aligned}
& \text { Top } 1 / 3 \text { of } \\
& \text { T-2 Ranking }
\end{aligned}
$$

Improved

6

Same or Deteriorated

\section{Authority Problems}

$$
\begin{array}{ll}
\text { Top } & 1 / 3 \text { of } \\
\text { T-2 Ranking }
\end{array}
$$

Improved

Same or Deteriorated
Bottom $1 / 3$

of $\mathrm{T}-2$

0

7

Bottom $1 / 3$

of $\mathrm{T}-2$

0

7

Realtionship with Adults

Top $1 / 3$ of

T-2 Ranking

Improved

Same or Deteriorated.

Physical Aggression

$$
\begin{aligned}
& \text { Top } 1 / 3 \text { of } \\
& \text { T-2 Ranking }
\end{aligned}
$$

Improved

6

Same or Deteriorated

1

Relationship with Parents

Top $1 / 3$ of

$\mathrm{T}-2$ Ranking

Improved

7

Same or Deteriorated
0
Bottom $1 / 3$

of $\mathrm{T}-2$

1

7

Bottom $1 / 3$

of $\mathrm{T}-2$

1

6

Bottom $1 / 3$

of T-2

2

5 
Withdrawl From Physical Contact

Top $1 / 3$ of

T-2 Ranking
Bottom $1 / 3$

of $\mathrm{T}-2$

Improved

5

0

Same or Deteriorated

1

The treatment program at Parry Center relies hoavily on the child's ability to build and utilize relationships with other people. The capacity to form a therapeutic relationship with adult staff mombers and mombers of the child's own peer group soem orucial in this structured, group living environment.

All 7 children in the bottom $1 / 3$ of the Time-2 Improvement Ranking showed no improvement or deterioration of their relationship with adults, peers and with authority figures. This was also true for 6 of these? same children in the area of physical aggression. All 7 of the children from the top $1 / 3$ of the Time-2 Improvement Ranking showed improvement in their rolationships with parents, 6 out of 7 showed improvement in the areas of physical aggression, authority problems, and relationships with peers.

It was suspected that children who were 1dent1fied on the BRS as having serious distortions of reality, psychotic activity, at Time-1 would have diffioulty forming therapeutic relationships and as a consequence would 
improve less than children who did not distort reality. However, this assumption does not appar to be correct. Six of the seven children in the top $1 / 3$ of the Time-2 Improvement Ranking and only two of the children from the bottom $1 / 3$ demonstrated reality distortions at Time-1. Future studies should attempt to approach the area of relationship formation and its association with treatment outcome in a more focused manner and attempt to identify the characteristics of children who appear to lack the capacity to form therapeutic object relationships.

We were surprised to discover that many of the variables which we thought would be highly associated with improvement during residency actually showed little or no association with the Time-2 Improvement Ranking.

Fig. 3-3a Variables Not Associated With T-2 Improvement Ranking

1) Number of Prior Placements

2) Length of Stay at Parry Center

3) Age at Admission

4) Number of Problem Areas at Time-1

5) Marital Status of Parents

6) Mental Health of Parents

Although our indices of the mental health of parents was not associated with the direction of behavioral change, this area could prove to be important in future studies. For many children, the pre-placement information in their case records was not complete enough to 
a determination of parental mental health. If more complete information can be obtained in future studies, the impact of the parent's mental health on the child's progress in treatment may become clearer.

The instability characterizing the lives of these children has been established earlier in the study. In Time 1 description this instability is evidenced by multiple placements before residence in Parry Center, the high incidence of living away from and the disrupted marital relationships of the majority of their parents. The children from the top $2 / 3$ of the Time-2 Improvement Ranking appear to have gained a greater degree of living stability than did the children from the bottom $1 / 3$ of the population of Time-2, of the 12 children contacted at Time-3, 6 of the 8 ohildren from the top $2 / 3$ of the Time-2 Improvement Ranking had only 1 placement since discharge from Parry Center. One of these same 8 children had 3 placements and 2 had 4 placements. Of the 4 children from the bottom $1 / 3$ of the Time-2 Improvement Ranking; 1 had 5 placements, 2 had 4 placements and 1 had 3 placements since discharge from Parry Center.

The follow-up interviews (Time-3) revealed that the Time-2 Improvement Ranking did not remain constant through time. At Time-3 we found almost a complete 
reversal of the Time-2 Improvement Ranking. In other words, many of the children from the bottom of the Time2 Improvement Ranking were found to be at the top of the Time-3 Improvement Ranking.

Table 5 Time-2 to Time-3 Improvement Ranking

$$
(N=12)
$$

\begin{tabular}{|c|c|c|c|c|}
\hline Code & $\begin{array}{c}\text { T-2 BRS } \\
\text { Score } \\
\end{array}$ & $\begin{array}{l}\text { T-3 BRS } \\
\text { Score } \\
\end{array}$ & $\begin{array}{c}\text { Dif. } T-2 \\
T-3\end{array}$ & $\begin{array}{l}\text { \% of } \\
\text { Change }\end{array}$ \\
\hline 220 & 23 & 5 & 18 & 78 \\
\hline 207 & 14 & 4 & 10 & 71 \\
\hline 210 & 15 & 7 & 8 & 53 \\
\hline $218^{*}$ & 4 & 2 & 2 & 50 \\
\hline 217 & 15 & 8 & $?$ & 46 \\
\hline 208 & 11 & 6 & 5 & 45 \\
\hline 202 & 12 & $?$ & 5 & 41 \\
\hline $209^{*}$ & $?$ & 6 & 1 & 14 \\
\hline $204 *$ & $?$ & 7 & 0 & 0 \\
\hline $214^{*}$ & 8 & 9 & -1 & -12 \\
\hline $215^{*}$ & 10 & 14 & -4 & -40 \\
\hline 211 & 5 & 10 & -5 & -100 \\
\hline
\end{tabular}

*Group Home Children

Two hypotheses were formulated to explain this surprising finding. It was surmised that adjustment to an institutional milieu may involve entirely different adaptational requirements than does adjustment to the community setting. Children who progressed rapidly within the structured institution may have experienced problems in adaptation once outside of this protective setting. Conversely, those children who were unable to respond to the expectations of the residential program 
appear to have improved significantly since their discharge from Parry Center.

Our second hypothesis is that those children who improved significantly during their stay at Parry Center had a much smaller range of possible improvement from Time-2 to Time-3. It might be expected that the children from the bottom $1 / 3$ of the Time-2 Improvement Ranking would experience some rather dramatic positive behavioral change. In addition, the normal changes resulting from maturation over time might be more visible in the children discharged at Time-2 as unimproved.

Perhaps the most surprising though inconclusive showing of the study was that the bottom 5 children from the Time-3 Improvement Ranking were all in the Parry Center group home at the time of the follow-up interview. This particular finding will be dealt with more extensively in a latter section.

\section{Parental Involvement in Treatment}

The prior study of Parry Center, "Eighteen Boys, A Descriptive Follow-up Study," reported the finding, "that the child whose parents support treatment has a much better treatment outcome." We have attempted here to look again at that relationship and have restated it in the following hypothesis, Parental involvement in treatment results in a positive behavioral change. Since this study has the more extensive quantitative tool, the 
Behavior Rating Scale, an answer should be easily attainable.

In the in-residence questionnaire we have rated parental involvement in treatment while the child was Living in Parry Center residence. Those results show:

Fig. 3-4a Parents' Involvement In Treatment

Parental Involvement

Children

A. Saw Parry Center Social Worker with goals of personal change

B. Saw Parry Center Social Worker primarily in support of child's treatment

C. No contact with Parry Center or child

D. Saw Parry Center Social Worker but did not support child's treatment

E. Saw Social Worker or therapist not part of Parry Center staff

The record reviewers further defined these statements by establishing that a parent who saw Parry Center Social Worker with goals of personal change was typically supporting the child's treatment to a higher degree than a parent who saw Parry Center Social Worker primarily in support of the child's treatment. Personal change goals typically meant more frequent contacts and a qualitative difference in involvement. A parent, for example, who had contact two or three times during 
a child's three or four year stay would be rated as supporting treatment but not with goals of change, and thus, the qualitative and quantitative difference in rating involvement.

A factor which makes it most difficult to evaluate parental involvement for some of the children is that parental ties had long been disrupted by prior placement in other settings, by family breakups via separation and divorce, and the addition of step parents into an already complicated social history. We do not refer in every case to the natural parents' involvement but to combinations of a natural parent and a stepparent, to foster families, or to whatever parents the child experienced just prior to Parry Center placement. Information on natural parents never was available in some cases.

By looking at the distribution of types of involvement of parents with the population's overall ranking in behavior improvement from time 1 to time 2, we can get a picture of possible correlations,

Table 6 Parental Involvement \& Improvement Ranking Type of Parental Involvement

$(N=21)$

$\frac{\text { Time } 1-2 \text { Improvement }}{\text { top } 1 / 3 \text { of population }}$ middle $1 / 3$

Lower $1 / 3$

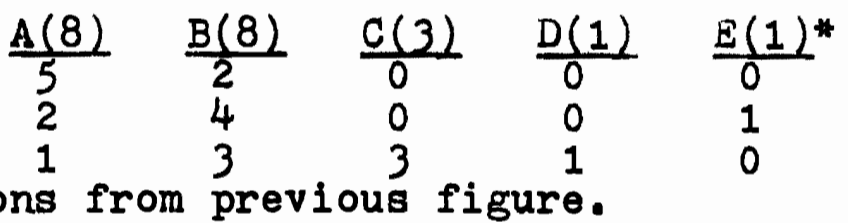


Though the trend is not pure and affirmative conclusions are uncertain, there is possibly a moderate association. All three of those children whose parents had no contact were in the lower $1 / 3$ of time 1-2 improvement scores, as was the one child whose parent had contact but did not support treatment. Of the seven in the top $1 / 3$, five had parents supporting treatment with goals of personal change and the other two had parents who supported treatment. However, the distribution for these two classes of parental involvement is too diverse and therefore makes the correlation between quantity and quality of parental involvement with possitive behavior change tenuous.

In retrospect, a more precise statement of the questions aimed at determining quality and quantity of parental involvement would have produced a clearer answer to this hypothesis. Frequency of parental contact was rather roughly estimated by record reviewers but the rating categories were not constructed to actually elicit exact number of contacts. For example, the category, "saw Parry Center Social Worker primarily in support of treatment," turned out to cover a broader range of parental behavior than expected. More specificity is recommended for future study of the question. 
4. Group Home Children

The last major research question of this study asks, "In what ways do children who are placed in Parry Center group homes differ from children who are not?" This research question has particular importance and implication because Parry Center has recently opened up an entirely new home. There are now two such homes administered by Parry Center to serve the needs of the children for whom such placement has been deemed appropriate upon release from residential treatment. The decision to place children in these group homes has sometimes been based on treatment plan (for example, when a child is judged not ready to adapt to nuclear family life) and sometimes has been based on non-availability of a family or other resource. The needs of these children are still seen as specialized to a degree and in need of a specialized response:

One of the first observations that can be made from the data is that none of the six children** in this

** Only six children are figured into the data for this hypothesis. It should be noted that two other children in the sample also lived in the group home at one time, though not currently. Child \#206 was released from Parry Center residence to his parental home but later was placed in the group home. He returned to his parental home and therefore is not counted in this data. Time 3 data was not obtained for him. Child \#220 was placed in the group home for several months after one period of Parry Center residence, but returned to residence and was later discharged elsewhere. Time 2 data for him was measured at the time of his last stay in Parry Center residence. Since then he had no group home contact. 
study who are now in Parry Center group homes rated in the lower $1 / 3$ on Time 1-2 Behavior Improvement Score. (These include \#218, \#211, \#204, \#209, \#214, \& \#215.) There is, in fact, an equal distribution of these children between the top $1 / 3$ and the middle $1 / 3$ in this rating, three in each. This implies that the children who were placed from residence to the group home had all made some behavioral improvement and none were considered to have problems severe enough to require institutionalization. All discharges were planned with the children having received maximum benefit from Parry Center residence.

The data analysis also shows that the parents of all the six children supported their child's treatment during placement, though only two saw staff with goals of personal change.

The average age of these six boys was just under 8 years at the time of their initial placement in residence, time one, compared to the average age of the total sample, 9 years. The children who went to group homes, then, seem to be from the younger end of the age range of the total sample. In fact, nine of the 21 children in the whole sample were older at time 1 than the oldest child who went to a group home. Apparently the older a child was to start with, the less likely he was to be considered for group home placement after residential treatment. 
Neither the number of prior placements a child experienced prior to time 1 nor length of stay in Parry Center correlates strongly with the group home children though the figures are interesting. Of these children one had 5 prior placements, one had 4 , and four had no prior placements to Parry Center. The average length of stay in residence for these six was 5 years, 1 month, compared to 3 years, 7 months for the total sample. The average stay, then, was longer for the group home children. All but one of these six had only the one group home placement from time 2 to time 3. The other (218) had two additional placements in this time.

The group home children were all progressing satisfactorily academically and cognitively. They were found to be progressing at age appropriate grade level in school with one exception. This was \#214 who is still attending school in an ungraded classroom at Parry Center, though he lives in one of the group homes. Of the others several were near high school completion and one had begun to attend a community college. This compares favorably with academic progress of the total time 3 sample.

As previously indicated the behavior improvement rating between time 2 and time 3 did identify a trend among the group home children toward the lower end of the scale. The last five children in this ranking were 
in group homes. The sixth child (\#218) rated fourth out of the 12 in time 2 to time 3 improvement. With this one exception, then, the group home children did worse than the total population after Parry Center residence. This presents a peculiar picture and compels us to search for explanation.

One possible reason for this finding suggests that because the surrogate parents who served as parental raters of time 3 behaviors were, in fact, Parry Center staff (by means of their positions as residential parents) they might be more severe in their ratings than other children's perents or parents surrogates. They would have less personal need to bias the ratings favorably than other children's parents or parent surrogates because of their training and experience. As it developed, two persons were responsible for all 6 of the group home children's ratings.

Another possibility is that since the group home children were more "captive" for the purposes of interviewing, their improvement is represented atypically compared to the percentage of completed time 3 interviews for the entire population. Those who were not located or were uncooperative may have lent a particular bias to the findings. A more likely answer is that 
children who are in group homes are there because they would be unable to adjust to a parental or foster home satisfactorily. Their time 2-3 behavior improvement rating merely reflects that the staff informally anticipated this at time 2 . Of course none of these explanations satisfactorily explains this finding about the group home children and it certainly could be a subject for future study. 
IV COMPARISON WITH PREVIOUS STUDY

OF EIGHTEEN BOYS

(Figures 1-12) 
COMPARISON WITH PREVIOUS STUDY

OF EIGHTEEN BOYS

The original (1970) study had a total population of 18, compared with the ' $N$ ' of 21 in the 1973 study. Whereas the 1973 research team was able to locate only 12 of the population of 21 for completing all phases of the program, the 1970 team was able to report on 17 of their 18 cases through all phases of the research. Prior to demonstrating further comparative data between populations, it will be necessary to differentiate significant features utilized in the two studies.

The original study, initiated at the request of the Parry Center Board Members, was designed and carried through by Parry Center staff members who spearheaded a team assembled from a number of other agency professionals involved directly or indirectly with children. The 1973 study was conducted solely by a team of graduate students, School of Social Work, Portland State University, who were engaged by Parry Center through the school's research program. The study served a dual purpose, i.e., presentation of further follow-up data 
to Parry Center and as a research project degree requirement for the students.

The data gathering instruments employed in the 1973 study (see Appendices) were modeled on those used in the 1970 study in order to maintain a continuity between studies. Two significant differences were the exclusion of a data gathering instrument for time three academic achievement and the inclusion of a Behavior Rating Scale. The former was excluded due to the difficulty presented by lack of teacher-student contact within the time frame alloted to the study. The latter (BRS) was designed specifically in an attempt to gain an improved behavioral recording device. The motivating reason for construction of this instrument was avoidance of difficulties experienced by the members of the 1970 study in describing their population. They reported:

"We attempted to group children at admission into some rough diagnostic categories. We confirmed a hunch that diagnostic language tends to hide more than it reveals. (1970 Study, p. 11).

The Behavior Rating Scale gave more detailed data than the diagnostic statements available in the records. It was felt that the BRS provided a more accurate assessment of the behavioral improvement (or impairment) than did assessment based on the single-question rating instrument from the In-residence questionnaire (see Question 9.). The single question ratingwas used as a measure of improvement/impairment in the 1970 study. 
Beyond the numerical difference in population (1970: $N=18,1973, N=21$ ), other demonstrable differences available for comparison are as follows.

Fig. 4-1 Age at Admission

$\begin{array}{lll} & 1970(N=18) & 1973(N=21) \\ \text { Range } & 6.75-11.42 \text { years } & 5.92-11.33 \text { years } \\ \text { Median } & 8.75 \text { years } & 8.5 \text { years } \\ \text { Mean } & 9.0 \text { years } & 8.6 \text { years }\end{array}$

Fig. 4-2 Length of Parry Center Treatment

$$
1970(N=18) \quad 1973(N=21)
$$

Range $\quad 0.33-4.58$ years

Median 2.? years

Mean 2.4 years

$1.0-6.91$ years

3.7 years

3.6 years

Fig. 4-3 Age at Time of Follow-up

$$
1970(\mathrm{~N}=18) \quad 1973(\mathrm{~N}=21)
$$

$\begin{array}{lll}\text { Range } & 14.0-21.0 \text { years } & 13.1-22.1 \text { years } \\ \text { Median } & 17.7 \text { years } & 16.7 \text { years } \\ \text { Mean } & 18.1 \text { years } & 17.0 \text { years }\end{array}$

Fig. 4-4 Placement Following Discharge

To Parents

To Parry Center Foster Home

To Other Foster Home

Institutionalized

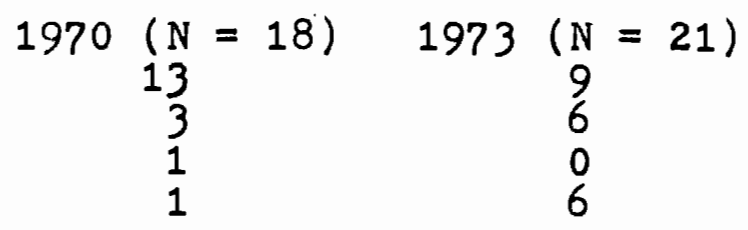

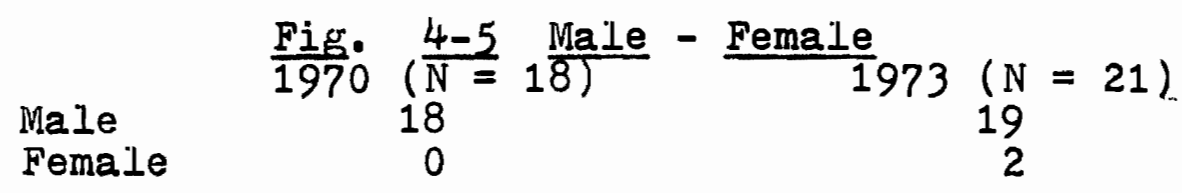


Fig. 4-6 Status of Natural Parents'

Relationship to Each other

Marriage intact

Separated

Divorced

Marriage terminated; death Unknown

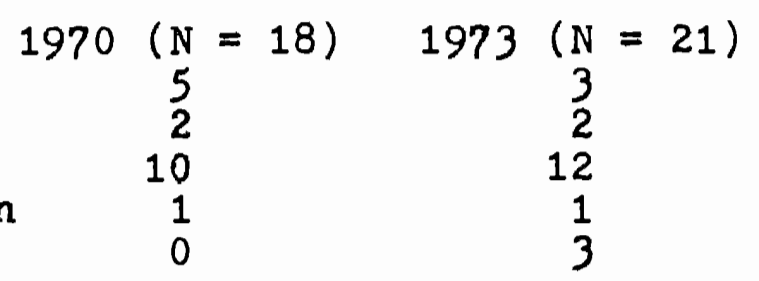

Fig. 4-7 Number of Pre-Admission Placements

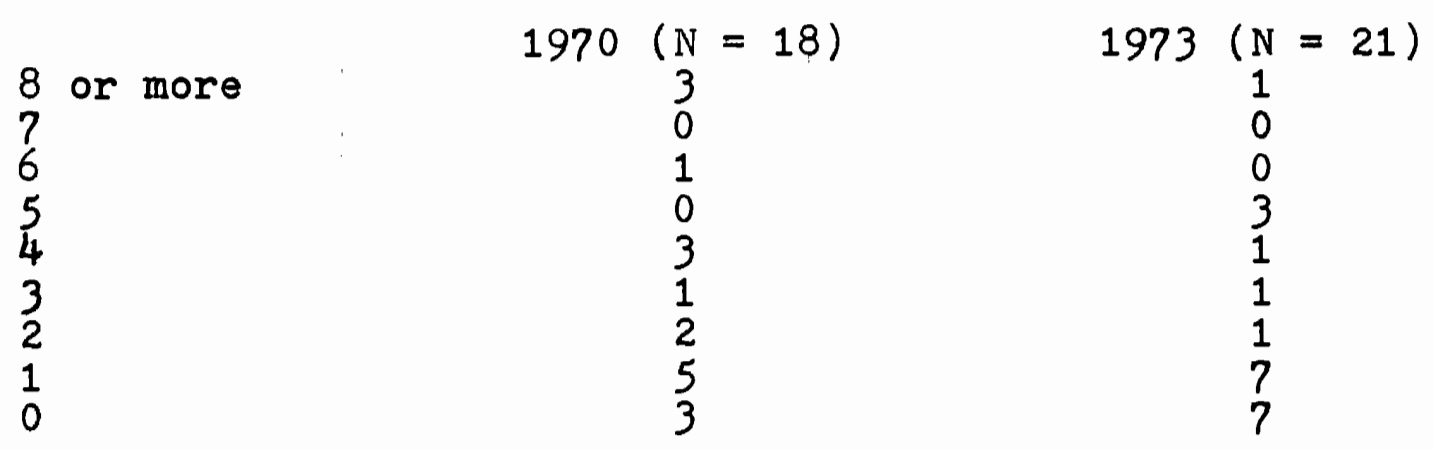

Due to the incompleteness of some records, or due to the fact that testing was either not given, or, if given, not recorded, an attempt to classify the range of I.Q. within the population was abandoned in the 1973 study, thus eliminating the possibility of $I . Q$. range comparison between the two studies. Other areas reported on in the 1970 study lacking sufficient data in the information compiled for the 1973 study for comparison purposes were medication records and school performance. Responsibility in handling money, socialization and self-awareness (see 1970 study) are not compared because the 1973 study relied more on the BRS to measure improvement/impairment.

Due to the difference in the age range at time 3 
of the study, the 1970 population showed employment for some of their group while all of the 1973 population was still within the school-age range.

$$
\text { Fig. 4-8 School - Work }
$$

Work

Sohool

Neither

$$
1970\left(\begin{array}{c}
N=18) \\
10
\end{array}\right.
$$

8

$$
1973(\underset{0}{N}=11)
$$

11

1

Fig. 4-9 Involvement with Law Enforcement Agencies

No Known Violations Minor Violations Felony

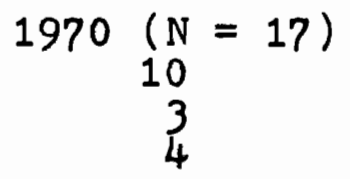

$1973(\mathrm{~N}=12)$

\section{Fig. 4-10 Type of Discharge}

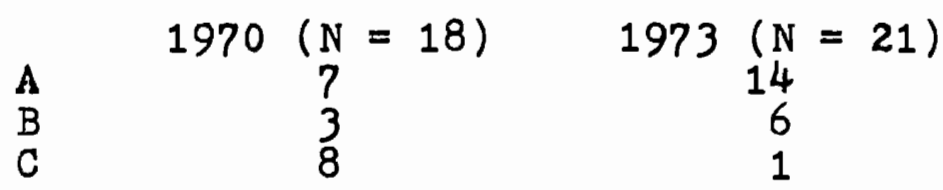

Code:

$A=$ Staff planned; maximum benefit received

$B=$ Staff planned, client unable to benefit from further treatment

$C$ = Discharged against staff advice

Fig. 4-11 Level of Improvement (Time 1 - Time 2)*

Significant improvement, major problem area 6

Improved some areas, little or no improvement other areas

Unimproved, or worse

* Based on single question rating, 1970 study, Question No. 8.

Although the 1973 study also contained a single question rating with an even broader assessment of improvement/impairment (see Appendix; In-residence data, 
Question No. 9), neither of these instruments offered as fine a means of discrimination as did the BRS.

Fig. 4-12 Parents Involved in Treatment

$\begin{array}{ccc} & 1970(N=18) & 1973(N=21) \\ A & 8 & 8 \\ B & 9 & 1 \\ C & (5)^{*} & 8 \\ D & (3)^{*} & 1 \\ E & 1 & 3\end{array}$

Code:

$A=$ Parents supported treatment with Center contact

$B=$ Parents did not support treatment; had Center contact

$C=$ Supported treatment with goals of personal change

$D=$ Saw other agency or therapist

$E=$ Not involved

*Due to differences in reporting final tabulations, the $\cdot C \cdot(5)$ and ' $D \cdot(3)$ categories are a breakdown of the total shown in ' $A$ ' (8) in the 1970 study.

With regard to this particular factor, a replication of the 1973 study with the 1970 study is significant in that treatment with parental involvement is indicative according to both studies of increased behavioral improvement possibilities, i.e., "...that the child whose parents support his treatment has a much better treatment outcome." (1970 study, p. 18).

Consensus among the collaborators of the 1973 study noted this significance with a view toward possible further research of the parental involvement factor. Both the 1970 and 1972 studies manifested overall improved behavior for those children whose parents were involved in treatment, and more specifically, for those parents involved in treatment, with goals of personal change. 
This information was abstracted from and based on case records. However, as will be noted elsewhere, the records were sometimes kept neither accurately nor regularly. Perhaps further research could elaborate on the "parental involvement" as well as "with goals of personal change." More accurate measurement might investigate the program supplied parents involved with goals of personal change and the types of people comprising this group. Further research design could consider a specific data collecting instrument with these objectives in mind. 
V CONCLUSIONS 


\section{CONCLUSIONS}

Our major concern with this study has been to describe in a systematic way, what this second treatment population was like. We attempted to complement and improve upon the first study done three years ago. Our major addition to this first study was the addition of the Behavior Rating Scale. We developed this as a tool for viewing children in a more objective way, that is, on their actual observable behavior. Although we feel we have accomplished this, we are also aware that this is only a beginning in performing research on these types of children. In adding another dimension with the scale, it became apparent to us how disturbed these children were. The amount of previous damage to these children gives impetus and rationale for developing new, more specific and sophisticated tools far viewing these ohildren.

One of our goals was not to determine treatment effectiveness of Parry Center, but to provide knowledge concerning the children the agency had for clients at that particular time period. Our findings seem to support our first hypothesis that behavior did improve 
over the three time period measurements, according to the instruments we used. This does lead us to the next question which is "What were the significant differences in experiences between the children who did improve and those who didn't?". To put this a different way, if we assume that Parry Center had a positive effect on these children, then given present behavior, how muoh was effected by various aspects of Parry Center and how much is attributable to normal growth and development, or other factors? One way to begin to answer this would be to study a population closer to the time of discharge than our study encompassed. Since this was not within the scope of the project, we leave this to future researchers.

Our conclusions around parental involvement in treatment is tenuous at best. The difficulty in defining parental involvement is probably the first and most crucial area we neglected, as our data shows. This question alone could provide a research project in the near future. The crucial differences appear to be around parents' supporting treatment, and parents' supporting treatment plus seeking personal change for themselves. For instance, a parent might be seeing his child in Parry Center and this might be a large personal change for the parent without seeking therapy for himself. It is an area that needs more specific detailed 
research. As another example, the present study shows a tenuous correlation between parents supporting treatment and the amount of behavior improvement in the child. What we did not answer is what types of parental involvement and programs could be offered that would help both the child and his parents the most. Another area still unclear at this time is that of relationships. Each one of our population scored high in the lack of ability to form a constructive relationship. What then, specifically, did the treatment program do towards improving or affecting the relation potential of these children?

This leads us to some tentative recommendations as a result of this study. Our primary took, the Behavior Rating Scale was used to measure the children three different times. The first two times our ratings were made from actual case histories, done by Parry Center staff. The third time, rating was made by actual observations done by the research team. We became aware of both the limits of our tool and the limits of the records. Specific areas we found limited were those of treatment goals, periodic descriptions of cottage life and some of the childrens'ongoing reactions to cottage life. We have some information that Parry Center is presently including this in childrens records. The limits of our 
own tool center around the reliability of describing and rating behavior from records versus data based on actual observation. We suggest that a program of research continue with emphasis being placed upon breaking down factors into more specific, objective, behavioristic categories to help isolate and control research varialbes. Additionally, we suggest that the implications of this research be considered tentatively and not as hard, conclusive facts. It would seem to us that more needs to be known about how difficult these children are to deal with and attempt to correct the traumas of their early lives.

In conclusion, three thyings are very clear to us from this study. The first is that the children Parry Center deals with are children with what could be termed different life experiences from that of normal children. There is some evidence of abuse and/or neglect which seems to characterize their lives the most. Second, behaviorally, the predominant symptom of thse children appears as an inability to form constructive relationships possibly necessary for a successful treatment outcome. Third, for this type of regearch to be of most benefit to the Parry Center in the future, a study might be conducted on a population more recently discharged and in a more specific, focused way than the broad demanding task of this project. 


\section{APPENDICES}

A. Schedule for Pre-residence Data 70

B. Schedule for In-residence Data 75

C. Follow-up Questionnaire--Parent(s) 80

D. Follow-up Questionnaire--Child 95

E. Criteria for Behavior Rating Soale (BRS) 109 
1. Name

(coded)

2. Age at placement:

years months

3. Source of referral:

4. Custody:

a Matural parents

b. Step-parent(s)

c. Agency

(spectry)

d. Other

(spectify)

If "Agency" or "Other," give:

Date of legal action:

Ward of court: Yes__ 110

Permanent___ Temporary

Initial identification of problem(s) for which child was referred to

Parry Center.

5. Last living situation prior to placement at Parry Center:
a. At home
b. Institution
c. Foster famfly
d. Other 
6. Previous placements:

Type of placement

Troster care, relatives,

Age at placement

Reason for move

institution, etc.)

1.

2.

3.

4.

5.

7. Adopted: Yes___ No

a. If adopted, age at placement with adoptive parents:

b. Age of parents at adoption: Mother

Father

8. Famtly:

a. Marital history

Present parents: Together

Hother: Separate Date Divorced Date

Father: Separated Divorced

Date

Date

Matural parents: Together

Mother: Separated

Date

Divorced

Date

Father: Separated

Date

Divoreed

Date

b. Age of parents at child's birth: Mother

Father 
8. C. Reference mother: recorded, significant heal th problems (includes psychiatric problems, attitudes toward pregnancy):

d. Physical complications during pregnancy or delivery

e. Evidence of early physical abuse or child neglect (includes periods of separation longer than one month in duration)

f. Age and sex of siblings: (specify " $n$ " for natural sibling and "s" for step-sibling.)



9. Source of famtly's income:

h. Specify type(s) of employment (occupation):

Father: Mother:

9. Child:

a. Birth: Normal___ Abnomal

If abnormal, explain:

b. Early 111ness(es) (type, duration and who cared for chl1d): 
9. c. Any early physical or psychological traumas:

d. First idențification of problem(s)

By whom:

Problem(s) jdentified

Age of child

Who inftiated contact seeking help?

e. Health: A summary statement concerning child's physical health.

f. Psychological testing (names of tests, results)

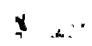

g. Neurological reports (Include EEG's and past references to possibilities of organic, brain damage)

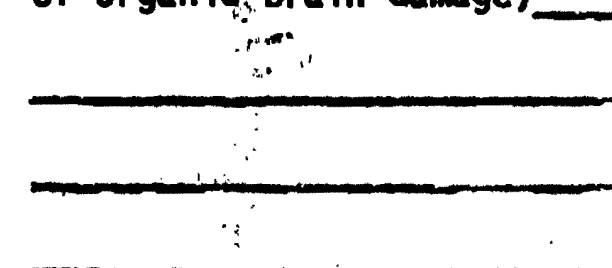

h. Medications used: Type Aprount. 
9. 1. Formal psychiatric diagnosis prior to placement:

J. Intake statement by Parry Center admission committee: 
APPENDIX B

Schedule for in-residence data 
1. Name (coded)

2. First descriptive-diagnostic statement by Parry Center staff:

3. Educational Program: Home teaching

Part-time public school number of months

Full-time public school number of months

Highest grade placement

Age appropriate: Yes___ Ho

4. Medication: Yes__ No___ If yes, spectfy types and amounts

5. Parents' involvement in treatment process during chlld's placement: (Circle letter of statement(s) that pertain to parent(s). Indicate whether circled statement refers to mother, father, step-parent, grandparent, etc.)

a. Saw Parry Center Social Worker primarily in support of child's treatment.

b. Saw Parry Center Social Worker, but did not support child's treatment.

c. Saw Parry Center Social Horker with goals of personal change. F $, \cdots, \ldots$ 
5. d. Saw Social Norker or therapist not part of Parry Center staff.

e. No contact with Parry Center or child.

6. Type of discharge:

a. Staff-planned discharge; child has received maximum benefit from Parry Center.

b. Staff-planned discharge; child is not able to respond or use Parry Center, needs other type of help.

Reason:

c. Discharged against staff advice, that is, discharged because parent or referring agency initiated this action.

Reason:

7. Final descriptive-diagnostic statement by Parry Center staff:

8. Level of Improvement (Circle letter of statement that most closely describes child at time of discharge from Parry Center):

a. Significant jmprovement in all areas of functioning.

b. Improved in major problem area.

C. Improved in some areas, but 11 ttle or no change in other areas.

d. Unimproved, not changed.

e. Appears more disturbed. 
9. Latest results of psychological testing while child was in residence (include name of test(s) and brief statement of results):

i.....

10. Age at discharge

$$
\text { years months }
$$

11. Length of placement years months

12. Did child remain in residence longer than recommended by Parry Center staff?
a. Yes
No
b. If yes, state the reason

c. Number of months chlld remained in residence when another resource would have been more appropriate:

d. What resource did Parry Center staff recommend:

13. Summary discharge statement about parent-chlld relationship 
14. Child's living situation following discharge from Parry Center:
a. Own home
b. Parry Center foster home
c. Other foster famfly care
d. Institution
e. Other

15. If foster famtly care, itho supervised the placement?
a. Child's Parry Center Social Worker
b. Other Parry Center Soclal Worker
c. Social Worker from another agency

(specrfy agency)

16. D1d child receive other post-residential services from Parry Center? Yes__ No___ If yes, spectfy

17. If child was seen by Parry Center staff on an outpatient basis, give frequency of contacts: Neekly Monthly other (specify)

18. Date case closed:

19. Number of months following discharge from residence to closure of case:

20. List agencies and persons who were provided with information about the child following his discharge from Parry Center.
a. Name of agency or person
b. Date of inquitry 


\section{APPENDIX C}

Follow-up questionnaire-parent (s) 
Code Name of Child

Person(s) Interviewed $-$

Relationship to Chlld

Date of Interview

Place

FOLLOW-UP QUESTIONNIARE - PARENT(S)

PART I. LIVING SITUATION

If interviewee is same parent/guardfan as at time of admission of child to P.C.:

Marital status at time of release of child from P.C.: married separated divorce

Present marital status: married separated divorced

If applicable, frequency of marriage since time of child's release from P.C.:

1. Child's first living situation after P.C. parents/relative/inst tution/other

2. Check if this is where child lives now. Yes__ No

3. If "yes", Has child lived at other places between P.C. discharge date and now? Yes No

(TO INTERVIENER: If "yes" to $\$ 3,1, e_{\text {. }}$, if child has lived in more than current home, get reasons for moves by question)

4. How did it happen that he moved from Home 11 to Home 12 ; from Home 2 to Home 13 , etc.

a. 2nd home relationship (to child) Teason for moving from former houi

b. About how long did he stay in home 12? 
Parent's Questonnaire

4. c. 3rd home relationship

reason

d. About how long did he stay in home \#3?

e. 4th home

retationship

months

reason

f. About how long did he stay in home \#4?



months

5. Who lives with your child now?

members and relationship

(TO INTERVIENER: Adapt question to living situation, i.e., fantly, other people.)

6. How would you say he gets along with these persons?

PART II. ACTIVITY (SCHOOL/WORK/OTHER)

7. Is he attending school? Yes__ No

(TO INTERVIEWER: If "no" to $7,1 . e .$, if child is not in school, skip to (29)

STUDENT:

8. If "yes", what school? name of hrgh school/college/etc.

9. What grade is he in?

10. What do his favorite classes seem to be? name of subject don't know,

11. What grades does he get in those classes? don't know 
Parent's Questionnaire

12. What are his least favorite classes? name of subject

don't know

13. And what grades does he get in those classes? grades

don't know

14. Generally speaking, how is (child) doing in school? (problems with grades, attendance, motivation, teachers, etc.)

Comments

15. Do you think your child will finish his (high school, college, etc.) education. Yes_ No_ Don't know

16. If "no", explain"

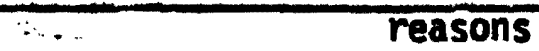

17. What rocational/occupational goals does the child have?

18. Does (ch11d) have a part-time Job? Yes__ No___ Don't know

19. Where does he work? employer

20. What does he do?

21. When does he work?. (after school, weekends, evenings?)

time

PART III. USE OF MONEY (CHILD IN SCHOOL)

22. About how much moniey does he make at his part-time job? 
Parent's Questionnatre

84

23. How does he spend his money?

activity or use

\section{other coments of parents}

24. Does your child get an allowance or spending money? Yes

No

(TO INTERVIEWER: If "no" to 124, skip to "28)

25. How much does he get?

anount by week

?

26. How does the child earn al lowance?

27. How does the spend it?

\section{type of activites}

28. What do you think would happen. If today, someone gave your child $\$ 500$ to spend any way he'd like? What do you think is the first thing he'd do with it?

\section{First chotce}

(IIISTRUCTIONS: This is the end of section for children currently in school; llow skip to 155)

PART II. ACTIVITY (CHILD NOT IN SCHOOL;

NOWSTUDENT:

29. Is your son working? Yes__ NC ___ Don't know (IMSTRUCtion: If "yes", skip to "35)

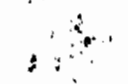

30. If "no" to 129 , what is he doing? बCETVIty

31. Has he ever had a self-supporting Job? Yes__ No ___ Don't know 
Parent's Questionnaire

32. When and what $k$ ind $(s)$

year and types of jobs

33. How is it that he's not working now?

\section{reasons}

34. How far did he "go in school?

Tast grade completed name of schoor

35. Where is he working?

Employing frim

part-time full-time

circte one

36. What kind of work is he doing?

\section{type of work}

37. Has he had other jobs before this one? Yes

No

Don't know

38. If "yes" to \$37.

Can you recall his first job?

Why did he leave it?

Can you recall his second job?

Why did he leave it?

Can you recall his third job?

Why did he leave it? 
Parent's Questionnatre

39. Number of jobs held since leaving school

number

40. Now I'd like to come back to his current job. I'm wondering if you have any Idea how he gets along there.

Does he say his boss is easy to work for? Yes No _ Don't know

41. Does (child) like the people he works with? Yes No Don't know

42. Why? $\therefore$. . comments

43. Has he ever talked about getting another kind of job? Yes No Yes Don't know

(TO INTERVIEWER: If "no" or "don't know", skip to 147)

44. If "yes", what kind?

45. Is he doing anything about getting the kind of job he talks about? Yes No Don't know

46. If "yes", what is he doing?

\section{activities/planning}

PART III. (continued) USE OF MONEY(CHILD NOT IN SCHOOL)

(TO INTERVIEWER: A redirecting comment l1ke "I suppose everybody who works does so for many reasons. One reason we all work is for money")

47. Do you know what his take home pay is? amount/week/month don't know

48. Is this enough for him to live on? Yes_ No___ Don't know

49. If "no", where is he feeling the pinch? 
Parent's Questionnatre

50. How does he spend his money?

\section{activity or use.}

51. During the past one month do you know if he has had to borrow money? Yes No Don't know

(TO INTERVIEWER? If "no" or "don't know", sk1p to "454)

52. If "yes", do you know from whom? retationship to Toaner

53. If "yes", do you know what for?

reason

54. What do you think would happen if someone gave hIm $\$ 500$ todayi what is the first thing he would do with it?

\section{activity}

PART IV. INTERPERSONAL RELATIONSHIPS

(TO INTERVIEWER: We've spent some time talking about work and money. Now I'd like to know a ilttle about how your child spends his time.)

55. Does he own a car? Yes No Don't know

56. Does he have a driver's ifcense? Yes No Don't know

57. When he wants to have a good t1me, what's he most 11kely do do? $\frac{\vdots}{\vdots}$ activity

58. Does he belong to any clubs or organizations? Yes No Don't know

59. If "yes", what are they? 
Parent's Questionnaire

60. Does he/she date? Yes_ No How often?

Trequency per wonth

61. What kind of activities does your child have with your famlly?

62. Now I'm going to ask you some questions about how he gets along with other. From what you know and see of (child) and his friends, which one of the following three statements best describes (child's) relationship with his friends. (ctrcle one)

a. He is a friendly person who trles to make friends.

b. He is a shy person who needs to be asked by others to do things.

c. He is a loner who'd rather be by himself/herself.

63. Now I'm going to ask you three questions about your child.

a. Does he find it easier to talk with boys or with girls? Boys___ Girls___ No difference ___ Don't know

\section{comments}

b. Does he find it easier to talk to his father or with his mother? (foster)Father___foster)Mother___No difference___ Don't know

\section{comments}

c. Does he find it easier to talk with adults older than himself or people his own age?

Older adults Peers No difference Don't know

\section{comments}

64. Now, I'd like you to tell me how your see your child. Which one of the following three statements best describes your chlld. (circle one) 
Parent's Questionnaire

64. a. He is very successfut.

b. He is moderately successfut。

c. He is not successful.

(TO INTERVIEWER: Give clarifying example of life areas appropriately to the child's age, $i_{\text {. }} e_{\text {. }}$, school friends.)

65. When (child)has a decision to made and needs to discuss it with someone, whom do you think he would go to first?

66. Are ther others to whom he would go? Yes No Don't know

67. If"yes", to whom?

relationshp

\section{comments}

68. Since your child left Parry Center, has he been in any trouble with the juventile authorittes or police? Yes Ho Don't know

(TO INTERVIEWER: If "no" to 468 , skip to \$71)

69. If "yes", what kind of trouble?

kind

70. Is he on probation/parole now? Yes_ No___ Don't know

71. In your estimation, what would you say is the best thing your child had going for him now?

72. What is the biggest problem(s) he has?

PART V. HEALTH

(INSTBUCTIONS: A comment Itke "we're more than halfway through. We've talked about your son's education, work and mohey. This next section deals with his health. But before we go into that, do you have any questions/comments?") 
Parent's Questionnaire

PART V. HEALTH (continued)

73. I'm going to ask you to give me an estimation of your chlld's health accordIng to one of three statements. Which of the three best describes him?

a. He is heidthier than most children of his age.

b. He is about the same as most children his age.

(circle one)

c. He has more health problems than most children his age.

74. Since January 1, 1972, has he missed any days of school/work because of sickness? Yes No Don't know

75. If "yes", what did he have? TIness

76. If "yes", how many days?

77. Is (child) taking any medication or drugs now? Yes No Don't know

78. If "yes", what and why? name of medcation and reason

79. If "yes", is the medication/drug helping? Yes No Don't know

80. Has the child $\mathrm{missed}$ work/school for reasons other than sickness? Explain

81. Since (child) left Parry Center, has he gone for help to any of the following persons? 
Parent's Questionnaire

81.

(INTERVIEWER: Read each and ask parent.)
a. physictan
a. physictan
b. psychiatrist
c. psychologist
d. socfal worker
e. minister, priest, rabbi
f. other (identify)

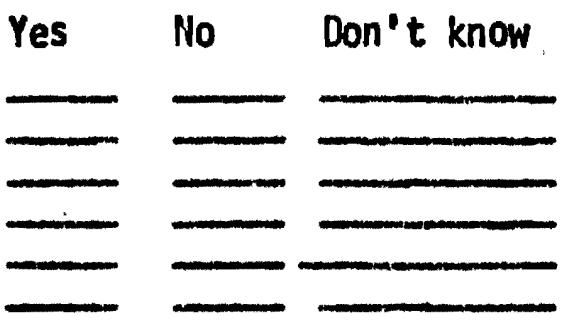

82. Is he going now? Yes__ No

83. Did (or does) it seem to be heiping? Yes__ No___ Don't know

PART VI. IMPRESSIONS OE PARRY CENIER ( 84 through 89 for parents only)

84. Can you remember how you first learned about Parry Center?

$$
\text { Who informed you and crrcums tances }
$$

85. When did you first talk with a staff member at Parry Center?
Before admission.
At admission
After admission

86. Can you recall your first impression of Parry Center?

87. What did you want from Parry Center for your chlld?

\section{recollection}

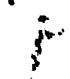

88. Who told (child) that he was going to Parry Center? 
Parent's Questionnaire

89. If answer to \#38 is "parent(s)", how did your child respond to the news that he was leaving home for Parry Cencer't

\section{Chitd's responses}

90. White he was at Parry Center, were ycu dole to vit hith? Yes l..... Ho compents

91. As you look back on your child's stay at Parry Center, what did you find most helpfui?

\section{comentis}

92. As you look back at your child's stay at Parry Center, what about the flace did (child) like best?

93. And what did he like the least?

94. What did you find the leat helpful? 
Parent's Questionnaire

95. If you knew a child who had troubles, would you suggest to the parents that they send him to Parry Center?
Yes
No
Can't say
Comments

96. Hell, we've finished all of the questions; I'm wondering if there is anything more you thiṇk the Parry Center staff could do to help k1ds and and their parents...

(INTERVIEWER ends by thanking parents, asking if they have other questions or comments.) 
APPENDIX D

Follow-up questionnaire-child 
Code Name

Date of Interview

95

Place

FOLLOW-LP QUESTIONHAIRE - CHILD

Part 1. LIVING SITUATION

"So why don't we get started by your telling ine what's happended since you left Parry Center."

1. Why don't you start by telling me where you went to live when you left Parry Center?

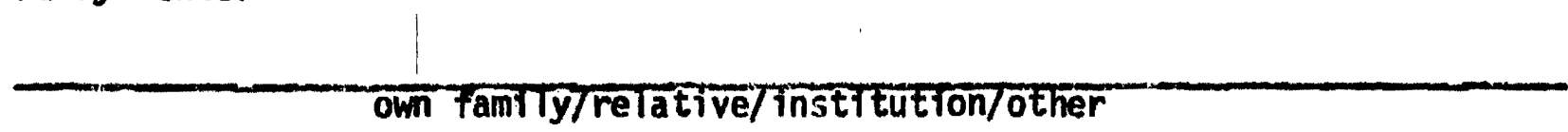

2. Is that where you are living now? Yes__ No

3. (If "yes") Have you lived there all the time until now? Yes No TO INTERVIEWER: If "Yes", skip to $\sharp 8$

4. If not, where?

relative/institution/other

5. (If no", to "2) Tell me where you went next.

\section{relative/institution/other}

6. (If "no", to \#2) How did it happen that you moved?

7. (If chlld has lived in more than two places, a comment like) "Let's see how many times you've moved since you left P.C." (Alternate statement): "Can you remember which places you lived since you left (parents, institution - answer to \#1)? 
Child's Questionnaire

8. Who are the people who live in your house now?

(TO INTERVIEWER: Some reassuring comment, Lead into next section with explanatory comment like, "That gives me a good idea of where you have been; now I'd like to know what you've been doing.")

\section{PART II: ACTIVITY (SCHOOL/LORK/OTHER)}

\section{For Students:}

9. What are you doing now? Are you in school? Yes No If child is not in school skip to $\$ 28$

10. If "yes". what school do you do to? name

11. What grade are you in? grade/class

12. What is your favortte class? name of subject or area of interest

13. What class did you get your best grade in? name of class

14. What grade do you get in your favorite class? grade (from last report card)

15. Now, what class do you like least? name of subject

16. Why? reasons

17. What grade do you get in your "worst" subject? grade(trom last report card) 
Child's Questionnaire

18. Do you have a part-time job? Yes__ Ho

TO IIITERVIEWER: If "no", skip to \#2la

19. What is it?

type of job

20. When do you do it? after school/weekends, etc.

21. a, Do you have an allowance? Yes_ No

b. How do you earn your allowance?

c. Do you have other spending money? Yes No Source

TTst and describe

d. How do you spend the money?

activity or use

22. If someone gave you $\$ 500$ today, what is the first thing you'd do with it?

23. Are you in any school activities, 11ke athletics, music, service clubs, etc.? Yes__ No

24. If "yes", what kinds? names or kinds of activities (particlpant or observer)

25. Do you think that you will fintsh (HS/college/trade school?) Yes____ Ilo

26. If "no", what will prevent you from completing? 
Child's Questionnatre

27. What vocational/occupational goals do you have?

\section{TO INTERVIEWER: Now go to Part IV "Interpersonal Retationships. \#58}

PART II. (continued)

For Mon-students:

28. What school did you last attend?

name

29. What grade had you completed whrn you left school?

30. What class did you ilke most?

Name subject or area of interest

31. What class did you like least?

name of subject

32. Are you working? Yes___ No

If yes, skip to $\$ 34$

33. If you are not working, how do you spend your time?

TO INTERVIEWER: For a child who is not currently working add this question:

Have you ever worked? Yes__ No

If "yes" go to 38 through 144 If "no" go to 48

34. Where are you working? 
Child's Questionnaire

35. What kind of work are you doing? (kilternate question: What is the title of your job?) Job ticte or kind of work

36. If in armed forces, did you have a choice of job assignment? Yes No Conments

TO INTERVIEWER: If there has been part-time employment, complete $\$ 37$ through 44 indicating which jobs are part-time.

37. Have you had other jobs before this one? Yes__ No

TO INTERVIEWER: If answer to \#37 is "no", skip to 145

38. If "yes", I'd be interested in knowing about the jobs you've had.

39. What was your very first full-time job?

\section{employer/kind of job}

40. Can you remember how it happened that you left your first job?

$$
\text { circlinstances for leaving (explore) }
$$

41. After your first job, what did you do next?

42. How long did you stay there?

$$
\text { months or years }
$$

43. Why did you leave? 
Child's Questionnatre

44. Where did you work next?

employer/type of Job

(TO INTERVIELER: Hopefully this will bring us to presentjob so a comment like, "so that brings us up to where you're working now. You said you were doing so-and-so.)

45. Is your employer an easy person to work for? Yes___ No explatn answer

46. Do you like the people with whom you work? Yes_ No __

47. Explain why

48. Do you see yourself staying for another year in the job you have? Yes No

49. What kind of job would you like to have?

describe

\section{comments}

PART III. USE OF MONEY

(TO INTERVIEWER: A redirecting coment, l1ke "I suppose everybody who works does so for many reasons but one reason we all work is for money")

51. About how much money do you make after taxes ctrcle one-hr., week, wonth

52. Is this enough for you to live on? Yes No

53. If "no", where do you feel the pinch? T.e. rent, fund and games, Tood, etc.

54. Have you had to borrow money in the last month? Yes No 
Child's questionnaire

55. If "yes", Who from?

retationship

56. If "yes" to $\$ 55$, What for?

reason

57. If someone gave you $\$ 500$ today, what is the first thing you would do with it? explain

TO INTERVIENER: Get a sense of priorities

PART IV: INTERPERSONAL RELATIONSHIPS

(TO INTERVIEWER: Now a reassuring-redirecting comment 11ke. "We've spent some time talking about work and money; now I'd 11ke to know a little bit about how you spend your time when you're not working - and the first question is about "how you get around.")

58. Do you have a driver's 1icense? Yes__ No

59. Do you oum a car? Yes___ No

60. When you want to have a good time, what do you do?

\section{kinds or activity; solttary or with others}

61. Do you belong to any clubs or organizations? (INTERVIEWER suggests.

"like a church group or hobby class, or hot rod club," etc.)

Yes

describe

No

comments

TO INTERVIEWER: If no, probe for use of time. 
Child's Questionnaire

62. Do you date? Yes___ No___. How often? Frequency per month

63. When you were telling me about how it is working on the job (going to school) and what it is you do with your spare time, I was wondering how you'd think your friends see you. Which one of the fol lowing statements would best fit how your friends see you. I'TT read all three and then go back over them.

"Mv friends would say... (Circle one)

a. (Chtld's name) is friendly person who tries to make friends.

b. (Child's name) is a shy person who likes people but needs to be asked to do things.

c. (ChIld's name) is a loner who'd rather be by himself.

TO INTERVIEWER: (After reading all three): "I'm going to read each of those again and you try to tell me which one of the three statements is most like you."

conilients

64. What kind of activities do you do with your "family"?

65. Now, a simflar kind of question but this time about how you think your parents (or substitute parents) see you. I'11 read three sentences and then reread them for you to tell me how you think your parents (substitute parents) most often see you. The first sentence:

TO INTERVIEWER: Give examples of 11 fe areas appropriate to child's age, such as, school, friends.

a. I think mo parents see me as being very successful.

b. I think mo parents see me as being moderately successful.

c. I think mo parents see me as being not successful.

(INTERVIEWER might say. While we're talking about how people see things, how does your future look to you.) 
Child's Questionnaire

65.

(INTERVIENER might say, "While we're talking about how people see things, how does your future look to your)

1) For example, if I were to ask you, "what's the best thing you have going for yourself, what would you say?"

2) And if I asked you. "What's the biggest problem you have, what would you say?"

66. Now I'm going to ask you three questions about which I'd like your own idas.

1) Do you find it easfer to talk to fellows or girls? fellows___ girls___ no difference.

\section{comments}

2) Do you find it easter to talk to older adults or people your age? older adults___ peers____ no difference

\section{comments}

3) Do you find it easier to talk to your father or your mother? father__ mother no difference.

\section{comints}

67. When you have a problem or a decistion on which you want halp, to whom would you go first? 
Child's Questionnaire

68. Since you left P.C. have you ever been in trouble with the juvenile authorities or police? Yes No

69. If "yes", what kind of trouble?

\section{describe}

TO INTERVIEWER: Also get the number of times.

70. If "yes". Are you on probation or parole now? Yes

No

PART V: HEALTH

(TO INTERVIELER: A re-focnsing "stretch time" comment needed - 11ke "We're more than hal fway through. We've talked about jobs, money and how you spend your time. llow, I'm going to ask you some questions about your health and then about Parry Center itself. But before we do that, do you have any questions or comments about what we have talked?")

(0.K. the next questions have to do with how you see your own health.)

71. If someone asked you to rate your physical health, which of the following best describes your health?

a. I am healthler than the average person mo age.

b. My health is about the same as other persons my age.

(circle one)

c. I have more health problems than most persons my age. (INTERVIEWER: Interviewee may read questions if this
is helpful.)

72. Since the first of this year have you missed any days of work/school because you were sick? Yes__ No 
Child's Questionnaire

73. If "yes", about how many days have you missed?

74. If "yes", what did you have?

75. Were you sick in $1971 ?$ Yes__ No

76. If "yes", How often?

77. Are you taking any medication now? Yes_ No

78. If "yes". What are you taking?

name of medication

79. If "yes". Why are you taking it?

medical reasons

80. If "yes", Do you think it is helping? Yes__ No

81. Have you $\mathrm{ml}$ ssed work/school for reasons other than illness? Explain

82. Since you left P.C., Have you gone for help to any of the following persons? Physictan?

Psychiatrist?

Psychologist?

Soctal Worker?

Minister/priest/babbi?

Other? (Identify)

83. Are you going now? Yes___ No____ (If yes)

84. Did (or does) it help?) 
Child's Questionnatre

\section{PART VI: IMPRESSIONS OF PARRY CENTER}

(TO INTERVIENER: "We're near the end and now I'd like you to think about how it was when you were at Parry Center.)

85. Can you remember who first told you that you were going to P.C.?

$$
\text { relationship to chtाd }
$$

86. Can you remember what they told you about $P_{0} C_{0}$ ?

\section{corment}

87. And now, think back about your first impressions of P.C. What do you remember? comments

88. Now I'd 11ke you to tell me who was most Important to you at Parry Center.

89. Were there others who were Important to you?

90. In what way was each of these people important to you?

91. When you look back at your $P_{0} C_{0}$ days, what did you like best?

Why?

92. What significant thing helped you most? 
Child's Questionnaire

93. What did you dislike most?

Why?

94. In what ways do you think you changed at P.C.?

95. Can you say how the changes happened?

96. If you knew a boy or girl who had trmubles, would you advise their parents to send them to P.C.? Yes No

97. He've just fintshed all of the questions I have about $P_{0} C_{0}$, I'm wondering ff there is something more you think the staff could do to heip kids at Parry Center?

\section{comments}

INTERVIEWER says that's the end of the questions, thanks him very much, asks if he has any more questions and says that if the child wants to read the final report he should call Parry Center in about two months. 
Child's Questionnaire

DO SHORT PARAGRAPH COMENT ON AFFECT AND APPEARANCE OF INTERVIENEE. 


\section{APPENDIX E}

Criteria for Behavior Rating Scale (BRS) 
CRITERIA FOR RATING BEHAVIOR DESCRIPTION

The following is a behavior rating scale designed to provide a picture of colmon behavior difficulties and an estimation of the severity of these problems. Under each behavior area is a scale ranging from zero to three, which provides for an estimation of the degree of behavior difficulty. Under each behavior area, please circle the number which most accurately describes your assessment of the subject, using the behavior description provided with each number as a guldeline for your rating. Please bear in mind that probably no child will exhibit all of the traits described in each category. In addition to circling a number, please add a brief sunmary (in the blank space provided in each area) which will best describe the behavior as you have observed it.

\section{VERBAL AGGRESSION}

0 no problem - polite, respectful, approprlate

1 mild problem - profanity, threats, over assertiveness, mildly offensive, uncontrol lable

2 serious problem - shouting, screaming, yelling, offensive to everyone, most difficult to control

3 very severe problem - yelling to exhaustion, requires restraint or isolation, hysterical spells, institutionalized because of threats or screaming, uncontrollable Summary:

PHYSICAL AGGRESSION - TOWARDS OTHERS, SELF, OBJECTS

0 no problem - (others) contact sports, rare fight; (self) accidental bruise; (objects) kicks tire in frustration

1 mild problem - (others) pushing, occasional bullying, shoving, slapping, hitting, use of size superiority, some fighting; (self) picking at body, scratching, inflicting blood wounds near skin surface; (objects) breaking or throwing inanimate objects

2 serious problem - (others) frequent fights resulting in school or work ejection, involvement of authorities (misdemeanor) $\mathrm{kills}$ or maims animals; (self) burns self, masochistic, may require medical treatment; (objects) vadalism, tearing or destroying clothes, furniture, toys 
PHYSICAL AGGRESSION - TOWARUS OTHERS, SELF, OBJECTS (continued)

3 very severe problem - (others) assaulic and battery, rape, murder, gang wars, planned cruelty, sadism; (self) suicide attempts or gestures, cutting wrists, overdose; (objects) arson, vast destruction, bembing

Summary:

WITHDRAWAL ACTIVITY - PHYSICAL CONTACT

0 no problem - normal affectionace response or very affectionate even if problematic

1 mild problem - minimal phystcal affection or rare

2 serlous problem - reaction to physical contact, crying, hiding, runaway

3 very severe problem - severe reaction, frequent runaways, fears touching, autism-withdrawal to a place, room, corner, for long periods of time

Surmary:

WITHDRAWAL ACTIVITY - VERBAL INTERACTION

0 no problem - converses normally or very locjuacious

1 mild problem - very quiet, must be urged to speak, requires patfence of others

2 serious problem - rarely says anything but that which necessary for minimal dafly needs

3 very severe problem - doesn't speak at all

Surmary: 


\section{LANGUAGE PROBLENS}

0 no problem - age appropriate vocabutary ana phrasing

1 mild problem - stutters, slurs occasionally

2 serious problem - work usage totally out of context, severe stuttering, slurring, blocking

3 very severe problem - doesn't talk, word sälads

Surmary:

\section{RELATIONSHIPS WITH PEERS}

0 no problem - has several friends, makes friends easily

1 mild problem - has few friends, abuses friendships but still able to keep them, gossips about friends

2 serious problem - manipulative, threatens friends, rejects friends or annoys them

3 very severe problem - has no friends, carries out threats, physically abusive, maximlzes distance between self and peers

Sunmary:

\section{RELATIONSHIP WITH PARENTS}

0 no problem - good relationships, support, love

1 mild problem - surface tension, excessive arguing, limited verbalization, little ability to share feelings with parent

2 serfous problem - constant hassle or constant avoidance

3 very severe problem - "war", relationshlp is in constant conflict parents exhibit no control, outright rebellion 
RELATIONSHIP WITH PARENTS (continued)

Summary:

\section{RELATIONSHIP WITH ADULTS}

0 no problem - able to talk easily to significant adults

1 mild problem - timid, shies away from adults, or challenging of adults, fert adult contacts

2 serious problem - into constant hassles, or constant fear of adult contact, aut:hority

3 very severe-difficulty with any kind of authority figure, constant rebell fous or annoying attitude, total lack of trust in any aduit, withdrawal, avoidance Sunmary:

\section{DAILY ACTIVITY - EATING PROBLEMS}

o no problem - normal intake, manners, control

1 mild problem - plays with food, messy, excessive or 1 imited appet1te, binges of candy consumption

2 serious problem - throws food, makes messes often, must be regularly urged to eat enough or not to overeat, requires involvement of physictan, steal ing of candy, food

3 very severe problem - excessive gorging, overeating, or undereating, malnourished tube or bottle fed

Summary: 
IOTOR ACTIVITY - POSTURE, ROCKING, HYPEPACTIVITY, EIZARRE IOVEMEIT

0 no problem - good posture

1 mild problem - rigid posture, blinking, nervous compulsion, mild tics

2 serfous problem - severe body tic, rockinn, tapping, twiddling of objects

3 very severe problem - catatonic posture, liysterical movements of body or limb, spinning, severe head banging

Summary:

\section{AUTHORITY PROBLEISS}

0 no problem - routine response to limits, some testing, angelic

1 mild problem - frequent violation of family rules, use of foul language as weapon, minor stealing, minor verbal rebellion to authority figures, occasional driving tickets, mild drug or alcohol usage

2 serfous problem - stealing, runaway, driving record, vandalism, gang activity, misderieanor, severe drinking and drug abuse

3 very severe problem - institutional involvement, felony, endangers others Summary:

\section{RITUALISTIC ACTIVITY - COAPULSIVE}

Puts shoes certain way before bed, walks to a certain place or path, cornpulsion to eat in a certain order, hand washing ritual, arrangement, order, frequent showering, sleeping mannerisms, head banging

Some of the above:

Exists: Does not exist:

If "exists", give brief sumary: 
DAILY ACTIVITY - TOILETING HABITS

0 wo probiem - reqular, clean

1 mild prohlem - nervousness causes inappropriate voiding occasionally, uncareful about self-cleanliness, occasional body odor, severe acne due to uncleanl ines 5, occasional body rash

2 serious proslem -- frequent loss o: control over bladder and bowels, falls to shower/bathe unless frequently reminded, constant constipation or irreqularity

3 very severe aroblem - requires help of other person in daily habits, or needs forcing to attend to self, severe dermatological problems

Summary:

\section{DAILY ACTIVITY - SLEEPING HABITS}

0 no problem - regular, normal amount:s of rest

1 mild problem - occasional sleep walk, nightmares, hard to get to sleep, sleeps too little, oversleeps

2 serious problem - sleep walks of ten, requires restraint, constant nightmares, needs medication to sleep, stays up late frequently, drinks self to sleep, cries self to sleep

3 very severe problem - needs someone in attendance to assure safety, requires medication to sl eep

Surmary: 
Feeling omnipotent, talks with God, df lusions $f$ grandeur, hallucinations, misinterpretation of obvious messages, haifeve, that demons or snakes 1 ive in the attic, paranoid, alcoholic and, or drug nduced hallucinations and delusions

Some of the above:

Exists: Does not exis i:

If "exists", give brief summary:

$10-31-72$ 